Article

\title{
Habitat Banking and Its Challenges in a Densely Populated Country: The Case of The Netherlands
}

\author{
Mechtilde M. J. Gorissen 1,* , C. Martijn van der Heide ${ }^{2}\left(10\right.$ and Johannes H.J. Schaminée ${ }^{1,3}$ \\ 1 Institute for Water and Wetland Research (IWWR), Radboud University Nijmegen, Heijendaalseweg 135, \\ 6525 AJ Nijmegen, The Netherlands; joop.schaminee@wur.nl \\ 2 Wageningen Economic Research, Prinses Beatrixlaan 582-528, 2595 BM The Hague, The Netherlands; \\ c.martijn.vanderheide@gmail.com \\ 3 Department Plant Ecology and Nature Conservation, Wageningen University, Droevendaalsesteeg 4, \\ 6708 PB Wageningen, The Netherlands \\ * Correspondence: hilde.gorissen@kpnmail.nl; Tel.: +31-6-55164159
}

Received: 28 December 2019; Accepted: 1 May 2020; Published: 6 May 2020

check for updates

\begin{abstract}
Due to a growing population, urbanization, industrialization and agriculture, the quality of nature and biodiversity globally has decreased enormously. This also applies to The Netherlands. Habitat banking is a market-based instrument for nature conservation and sustainable development to counteract this decrease. We analyze under which conditions habitat banking can indeed offer possibilities and opportunities for improving biodiversity, nature conservation and sustainable development in The Netherlands. For this, we first identify the shortcomings of mandatory nature compensation in The Netherlands and link them to current innovations in Dutch nature policy. In addition, we investigate three necessary instruments for a successful habitat banking system: (1) a system for nature valuation, (2) a method for creating ecological opportunity maps, and (3) the institutional setting in which habitat banking can be operationalized. We conclude that habitat banking contributes to solving the problems for nature and biodiversity and to sustainable development in The Netherlands, provided that this is primarily addressed (i) in the domain of voluntary nature compensation, (ii) in bottom-up pilots for integrated area development (in this article shortly referred to as area pilots) where the widest possible range of owners and users of these areas is involved, (iii) in a context of participatory decision-making and (iv) learning and experiment en route to social-ecological systems (SESs). To actually realize the added value of habitat banking for The Netherlands, further scientific research is required to collect and analyze empirical data from relevant stakeholders.
\end{abstract}

Keywords: nature compensation; habitat banking; voluntary compensation; socialization of nature; sustainable development; integral area development; socio-ecological learning; evolving human-nature relationships

\section{Introduction}

In recent decades, the quality of nature worldwide has deteriorated sharply due to a growing population, urbanization, industrialization and agriculture [1-4]. The same applies to The Netherlands [5]. Between 1900 and 2000, biodiversity in this densely populated country declined by more than $60 \%$. (Percentage is relative to the base year 1700 as used by the PBL Netherlands Environmental Assessment Agency (Planbureau voor de Leefomgeving) for its biodiversity assessments (globally and European). For national biodiversity assessments, PBL uses the base year 1900 [5].) Despite many policy efforts, there has not yet been a steady recovery. The spatial, water and environmental conditions for nature in The Netherlands are not yet sufficient to achieve the nature objectives agreed in Europe [1]. In addition, mandatory compensation to counterbalance the ecological 
impacts of development projects on ecological networks in The Netherlands is not yet adequately effective [6]. Furthermore, as a consequence of relatively recent budget cuts in nature policy, the available resources (money and land) in The Netherlands are insufficient to achieve the European biodiversity targets [7]. (To illustrate: In the reference year 2010, about $45 \%$ of the species in The Netherlands covered by the EU Birds and Habitats Directives were subject to conditions sufficient for sustainable conservation. If nature policy were to remain unchanged, this percentage would decrease further [7].)

On the contrary, more and more stakeholders, like citizens and businesses in The Netherlands recognize the importance of a sustainable society that manages their rich ecological, cultural and environmental heritage in a responsible manner [8-12]. This trend has also been identified internationally $[13,14]$. New stakeholders want to make a positive contribution to nature, biodiversity and to their environment, but they need a policy perspective that meets their interests [15]. This aligns well with the current policy innovation of the Dutch government aimed at socialization of nature [16]. Socialization of nature is defined as "a movement in which citizens, businesses and social organizations take more initiative and/or participate in, and/or are made jointly responsible for, the realization of public values in the field of nature" [17]. (The government agreements made in connection with current policy innovations in The Netherlands are expected to result in an improvement from $45 \%$ to $65 \%$ of the European nature objectives in 2027. This means a residual task of $35 \%$ for Dutch society in the coming years [7].) In this respect, habitat banking offers incentives to a broad range of nongovernmental stakeholders to participate in nature conservation and sustainable development.

Habitat banking is a market-based instrument for nature conservation and sustainable development, based on the principle that biodiversity losses that accompany economic development can be compensated by creating equal biodiversity gains elsewhere. Stakeholders creating biodiversity gains can convert the biodiversity values created into biodiversity credits or nature credits and store them in a habitat bank from which the stakeholders causing a biodiversity loss can buy them. A central board for habitat banking ensures regulation, validation and verification throughout the process [18-20], as shown in Figure 1. The supply of nature credits and the demand for these credits to compensate for the damage to biodiversity (biodiversity debits or nature debits) are traded on a habitat market. Credits can be produced in advance, without ex-ante links to the debits they compensate for, and can be stored over time [20]. This offsetting approach leads to nature conservation becoming a more integral part of society and can even go along with better ecological results in tandem with economic development [14,21].

Often, the goal of transactions on a habitat market is "... to achieve no net loss of biodiversity, and preferably a net gain, on the ground with respect to species composition, habitat structure and ecosystem function, and people's use and cultural values associated with biodiversity" [22] (p.6). As habitat banking is already practiced in other continents including the United States and Australia [19], Eftec et al. $[19,20]$ examined the potential use of habitat banking in the EU as an economic instrument for biodiversity protection. In addition, the researchers extended the initial definition of no net loss (NNL) of the Business and Biodiversity Offsets Programme (BBOP) [22] to include " ... ecosystem services, including livelihood aspects" [19] (p.59). They argued that the potential for habitat banking is still limited, but there is some evidence of interest related to voluntary actions driven by social entrepreneurship (corporate social responsibility-CSR). With appropriate ecological and social criteria, a viable habitat banking market could be developed in the EU. Further action to develop habitat banking as a policy tool is therefore justified [19]. 


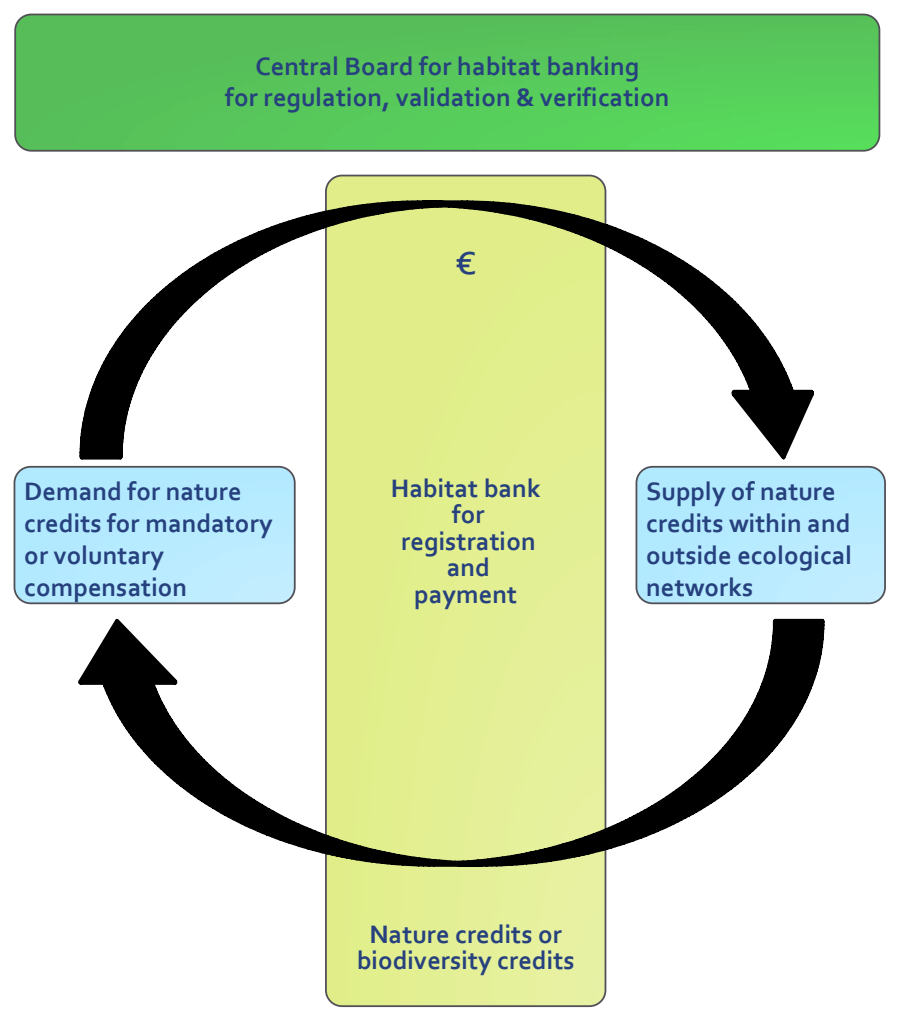

Figure 1. Essence of habitat banking and associated organizational structures [15].

Several authors discuss the potentials for habitat banking, both at European $[19,20,23,24]$ and Dutch level $[15,18,25]$. Numerous studies consider habitat banking to be a more efficient tool for nature conservation than current practice and make suggestions for its design [18,23-26]. But there is also criticism on habitat banking. This concerns, among other things, the technocratic approach, the commodification of habitats for exchange, and the notion of habitat banking as an inherent permission to burden and destroy the environment, which is at odds with ethical and moral principles.

Our central research question is in which way habitat banking offers possibilities and opportunities for improvement of biodiversity, nature conservation and sustainable development. And additionally, how can habitat banking further support mandatory and voluntary nature compensation, so that they contribute more adequately to this improvement? We argue that habitat banking in The Netherlands has not been very successful in practice, because it has so far focused primarily on the interests of economics (profit) and ecology (planet), which results in social (people) interests being pushed into the background. Habitat banking, however, enables Dutch companies, governments, civil society organizations and citizens to contribute to the realization of NNL [18].

The originality and value of this article relate to the contributions to the already existing literature on habitat banking in the following ways. It provides: (i) a review of the most recent developments in Dutch nature policies and their links with habitat banking; (ii) a combined view of issues and knowledge that were previously examined separately; (iii) a description of a learning and experimentation process for voluntary nature compensation, including socio-ecological learning, necessary for implementing a habitat banking system; and (iv) starting points for further interdisciplinary research to obtain empirical data among relevant stakeholders and deepen insights into habitat banking in practice.

In this article, we first describe the methods used (Section 2). Our results are described in Section 3, Section 4, Section 5, Section 6, Section 7, Section 8 . First, we identify the shortcomings of mandatory nature compensation and link them to current innovations in policy development as a result of transitions in Dutch society (Section 3). Next, also considering critical remarks on nature compensation and habitat banking (Section 4), we propose a possible design of habitat banking in 
The Netherlands (Section 5). We investigate three necessary instruments for a successful habitat banking system (Section 6, Section 7, Section 8) and finally summarize relevant discussion points (Section 9) and our conclusions (Section 10).

\section{Methodological Approach}

We have explored the solutions habitat banking could offer to enhance nature compensation and sustainable development in The Netherlands. To this end, we conducted interdisciplinary literature research from both scientific and grey literature, occasionally supplemented by our own previously unpublished research. We validated the results of our study by triangulating our findings [27] by means of the following: (i) Dialogue with relevant stakeholders (individually as well as in focus groups) in the field of research, government strategy and policy (i.e., nature policy, rural development, economy and innovation, and spatial planning), and area development (in the years 2015, 2016, 2018, and 2019). (ii) A not yet published, representative survey among citizens $(n=1043)$ and businesses $(n=357)$ in Limburg about, among other things, voluntary nature compensation, commissioned by the Dutch province of Limburg (2015) The current article places habitat banking in the broad context of, on the one hand, a technocratic-reductionist value assessment of nature and biodiversity based on the idea of objective truths about it, and, on the other hand, a holistic approach to nature and biodiversity in which socio-cultural and underlying human and moral values should play an equal role to achieve sustainable development, social sustainability and ultimately a sustainable human-nature relationship. By linking these two approaches, abuse of habitat banking can be prevented (see Sections 5 and 9). We have not yet published the results of this survey, because that broader context is crucial for this. (iii) A survey among policy staff of Dutch provinces involved in nature compensation (2015). (iv) Critical reviews and corrections of our texts by relevant researchers of the PBL Netherlands Environmental Assessment Agency $(2016,2019)$ and Wageningen Economic Research (2016). A list of the stakeholders involved can be obtained from the first author.

The nonmonetary nature valuation systems available for The Netherlands have been developed for a certain application area, for example for area development or mandatory nature compensation, and therefore not always directly suitable for habitat banking. In Section 6 we investigate the following nature assessment systems for their usability for habitat banking in The Netherlands:

1. PBL Netherlands Environmental Assessment Agency [28]. This nature valuation system is primarily developed for application in sustainable and integrated area development. For a critical reflection on this we refer to [29]. PBL further developed this nature valuation system for aquatic nature in 2014 [30].

2. The valuation system proposed in the preliminary study on habitat banking [18]. This is primarily designed for voluntary compensation.

3. The Instrument for Nature Points of the National Green Fund \& Van Groenendael [31,32], intended primarily for mandatory compensation and offsetting.

4. Aggregated nature valuation system of the BEE (Biodiversity Ecosystems and Economy) Platform [33].

In order to give an indication about the usefulness of the nature valuation systems 1 to 4 in bottom-up area pilots for habitat banking, we assess them qualitatively from scientific as well as grey literature. For this purpose, we use the following assessment criteria, some of which have already been proposed in part by [31-33]:

a. "Ecologically justified", so that no net loss of biodiversity can be guaranteed on the basis of the calculated values of nature and biodiversity (credits and debits), without unnecessary economic or other social developments being blocked.

b. "Workable", meaning simple and payable. Working with nature valuation systems should therefore not be cost-increasing and preferably cheaper than current practice. One of the 
questions underlying this assessment criterion is therefore to what extent working with a certain nature valuation system can be done independently of expert judgement.

c. "Credible": This is determined by features such as transparency, objectivity and unambiguity, with which the system's societal support increases. Whether the criticism on habitat banking is justified, i.e., whether or not an ecologically sound and consistent approach is being taken, everyone should be able to judge for themselves on the basis of a nature valuation system that enables social control and adjustment.

d. Broadly and generally "applicable". A nature valuation system has added value if it can be applied not only in the calculation of nature value, but also for other areas of application, such as the monitoring and evaluation of nature's values, tendering procedures and for comparison of alternatives in environmental impact assessments and cost-benefit Analysis (CBA). Furthermore, for the operationalization of habitat banking, it is important that a nature valuation system can be applied in all distinct area categories, both within and outside protected nature areas. The broader and more generally applicable the valuation systems used, the more likely it is that in the end a proliferation of different valuation systems can be prevented.

\section{Nature Compensation and Habitat Banking in a Changing Society in The Netherlands}

In order to be able to identify the potential role of habitat banking for nature compensation and sustainable development in The Netherlands, it is first necessary to understand the shortcomings in current nature compensation practices. In this section, we further explore the opportunities and possibilities of changing nature policy to habitat banking as a better alternative.

\subsection{Shortcomings of Mandatory Compensation in The Netherlands}

Numerous studies $[6,34]$ indicate that mandatory nature compensation in The Netherlands has major shortcomings. It (1) does not lead to the desired results for biodiversity, (2) leaves insufficient room for (socio) economic developments, (3) is expensive compared to what it yields, (4) is often not (or has difficulties in being) physically feasible, and (5) is complex and not transparent. As a result, social control is difficult and registration, control and enforcement by responsible authorities are not adequately carried out [35]. Kalisvaart and Van Groenendael [34] summarize the results of five studies into the functioning of nature compensation in the period 2003-2012 into the following key issues: (a) late compensation in relation to the time of the intervention, (b) the insufficient quality of compensation nature, (c) unclear allocation of responsibilities, (d) fragmentation of compensation nature, and (e) insufficient control due to lack of registration of the compensatory measures, so that after the implementation of the compensation, the allocation of responsibility for managing the new area(s) of nature is seldom completed. Significant shortcomings have also been identified with regard to the legal frameworks and regulations, in the sense that (i) the rules are too complex, so initiators do not know where they stand, (ii) the knowledge of rules concerning nature compensation among competent authorities and initiators is limited, (iii) the result is not transparent due to the accumulation of relevant protection regimes and compensation obligations, and (vi) the existing differences between provinces cause confusion. This is due to their own ability to regulate the compensation principle with regard to ecological networks such as Natura2000 and the Dutch Nature Network (the so-called Nature Network The Netherlands- $-\mathrm{NNN}$ ) and the protection of other areas of nature at provincial or regional level [36].

The decentralization of nature policy in 2013 may even have exacerbated the situation. Gorissen et al. [15] (p. 18) showed that provinces' autonomous policy responsibility resulted in different choices with regard to the compensation principle (e.g., on the application of weighting factors for recovery time, quality and rarity of habitat types). Furthermore, provinces opted more often for financial compensation instead of compensation in kind. Some provinces also broadened their nature compensation policy to include social compensation policy or spatial quality policy, thus ensuring integrated area development and further quality gains than only those of biodiversity. In addition, 
so-called perverse incentives have been identified that could undermine nature compensation policy. These include incentives for (i) acceleration of the decline of baseline biodiversity, (ii) the phasing out of conservation measures that are not being set off, (iii) the marginalization of volunteering for nature conservation, and (iv) provoking false public confidence in environmental outcomes as a result of marketing offset actions as benefits [37]. All in all, the complexity of mandatory nature compensation is increasing rather than decreasing.

\subsection{Socialization of Nature: Changing Strategies that Fit in with Habitat Banking}

In past decades, the domain of nature policy and nature conservation has increasingly been dominated by the national government [38]. In this context biophysical experts with their scientifically founded technocratic positions, were considered 'able to speak the truth to power' [39]. At least some of the shortcomings of mandatory nature compensation can be attributed to this trend [40-43]. Policy innovation aimed at the socialization of nature should reduce the resulting distance between nature policy and society [17] and support a gradual evolution of a dynamic and mutual relationship between man and nature [44]. This policy vision arose from the recognition of the importance of a balanced relationship between people and nature [45-47], not only for nature and biodiversity itself, but also for human health and social well-being [16,48-52]. In this regard, the fundamental attitude of man towards nature is referred to as culturally reflexive stewardship, (defined as 'stewardship in a subjectivist and culturally dependent sense of the term value' [53]) [54], or green stewardship [55], and indirect reciprocity (in the sense of "I help you and somebody else helps me"). This mindset requires monitoring, not only partners in continuing interactions but also all individuals within the social network [56] (p.1291). To achieve the intended sustainable human-nature relationship, various interlocking top-down and bottom-up strategies or attitudes towards nature as shown in Figure 2 must be deployed [57-59]. From the top-down perspective of the government [60], these can be referred to as (i) marketization (i.e., transfer of responsibilities towards nature to the market) and (ii) civic participation or transfer of governmental responsibilities to the energetic society [61] or civic society $[17,59]$. To date, the recent practice of policy debates on socialization of nature in The Netherlands is still often based on either marketization $[9,62]$ or civic participation, without mutually balancing the two approaches $[63,64]$.

\section{Government}

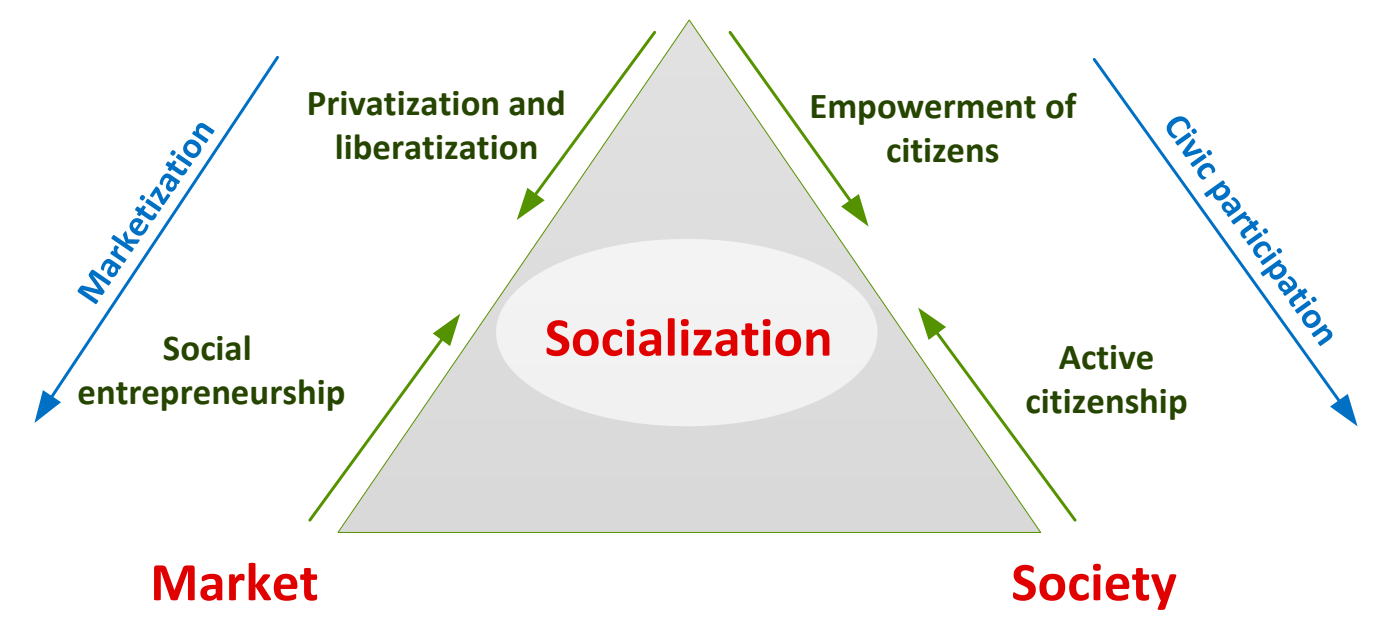

Figure 2. Changing strategies of government, market and society [57-59] (reproduced with some modifications with permission of M. van der Steen [57]). 
The new Environmental and Planning Act of The Netherlands, which enters into force in 2021, may offer more possibilities for private considerations and initiatives of companies, citizens and civil society organizations. However, the exact impact on nature conservation cannot yet be fully determined [65]. In view of the identified shortcomings of mandatory nature compensation, this strategy alone will not be sufficient in the coming years for the desired development of sustainable and resilient interactions between human societies and the natural environment. This means that sustainable development, characterized by a durable integration of economic activities (profit) with social (people) and environmental (planet) priorities [51,66-71], will not be achieved with only the current approach of mandatory compensation. On the other hand, increasing attention is being paid to the importance of nature outside protected nature areas [16,72]. In these areas in particular, voluntary compensation can have added value, not only for biodiversity, but also for society $[15,23]$. In order to help achieve nature conservation and economic developments, various parties in The Netherlands consider habitat banking as (i) a promising alternative to the current mandatory compensation, (ii) an instrument to enable voluntary compensation by companies and citizens by offering new action perspectives for improving nature and their environment and (iii) facilitating validated trade-offs between the interests of nature and the economic and social development needs of stakeholders, and all in all, (iv) a driving force for the envisaged social innovation, as shown in Figure 2 [15,18,20,34,73-75]. Further examples are the Platform for Biodiversity Ecosystems and Economy (Platform BEE) [76], the Dutch national committee of the International Union for Conservation of Nature (IUCN NL) [77], and the Dutch Natural Capital community [78]. PBL Netherlands Environmental Assessment Agency (PBL) argues that habitat banking can stimulate the connection between nature and the economy [79] (Natuurlijk Kapitaal Nederland. Natuur and economie verbinden [80]). Habitat banking combined with culturally reflexive stewardship and indirect reciprocity at local or regional level leads to the development of strong self-governing communities that organize their own natural capital, its management and sustainable use $[58,81,82]$.

However, critical remarks are also made about habitat banking. We will address these in the next section.

\section{Critical Remarks on Nature Compensation and Habitat Banking}

Nature compensation and habitat banking are generally seen as ways to achieve equivalence between ecological losses and gains, and primarily as technical challenges [22,23,83]. This technocratic view and the associated growing confidence in a philosophy of social engineering towards nature [74] that characterize a reductionist-mechanistic or technocratic paradigm [84-86] have profound consequences: (i) the practice of nature compensation considers nature as isolated biodiversity units that can be easily defined, measured and exchanged across time and space; (ii) it redefines conservation as an exchange of credits, implying that the value of nonhuman nature can be determined by reductionistic value assessments and even by a financial price; (iii) it denies the locational specificity of biodiversity, ignores wider dimensions like the 'sense of place' for people and deepens nature-culture and nature-society gaps in the human-nature relationship; (iv) it links conservation with land development and economic growth, anticipating and circumventing conflicting positions. This all leads to the conclusion that the problem of biodiversity loss due to economic development is being depoliticized by presenting nature compensation as a technical issue $[74,87]$ that only requires stricter application of the nature compensation rules and careful design of offsets and habitat banking initiatives. Regardless of whether this is a realistic option in a densely populated country like The Netherlands in the current time of decentralization [2], a more fundamental question is whether it is possible to assess, compare and equate the damaged nature in one place with the ecological result of its restoration elsewhere [23]. Environmental philosophers claim in a general sense that ecological restoration through technocracy does not work because nature cannot be made by man [47].

The economic logic underlying nature compensation and habitat banking is also criticized. In this regard, a number of authors identified the risk of further utilization and commodification of 
nature [14,87-90]. Commodification of nature is defined as a process of transformation of nonhuman nature into an object of trade [59] (p. 20). Gómez-Baggethun et al. [91] analyzed an analogous process of commodification with respect to the concept of ecosystem services, identifying a slow movement over a period of three decades, from the original economic concept of the benefits of nature as use values in Classical economy towards their conceptualization in terms of exchange values in current neoclassical economy. The authors consider the linking of demanders and suppliers in real markets through the design and implementation of institutional structures as the final phase of a process of commodification. Habitat banking could become one of those institutions [59] (p. 22). Institutional structures are able to adapt human behavior and motivations [92,93]. For example, by creating economic incentives for nature conservation, market-based mechanisms can lead to an increase in individualism and competition in societies previously structured on the basis of community and indirect reciprocity values [56]. All in all, such calls reinforce extrinsic values associated with the pursuit of prestige, power, image and status, further suppressing human and moral values with regard to caring for others and the environment. This means that there are still many socio-ecological uncertainties on the possible side effects of transferring utilitarian market-based principles to nature conservation [91].

Nature compensation and habitat banking also involve a number of potential or perceived risks which may lead to under-utilization of the earlier stages of the mitigation hierarchy and the overruling of conceptual frameworks outlining guidelines and evaluation criteria [14,23] (p.9). This lowers the threshold for project approval and thus facilitates permanent land-use change with negative net effects on nature and biodiversity $[23,87]$. Destroying nature would thus become acceptable if the damage to nature could be repaired elsewhere [89]. Habitat banking as a "license to trash" $[2,23,94]$ or a "license to destroy" [89] for project developers could easily and increasingly lead to compensation being implemented outside the geographical boundaries of development sites (off-site compensation), thus allowing developers to increase their net developable area [87]. Such a "license to operate" for developers, frequently referred to as "greenwashing" [90] or "un-green grabbing" ("un-green grabbing" is defined as the current neoliberal process of intensifying the exploitation of protected natural areas) [95], often leads to unsustainable results.

Human societies depend on myriad functioning ecosystems in innumerable ways that are far from being fully understood [14]. The generally accepted intention of offsetting and nature compensation in Western society focusses solely on preventing net loss of biodiversity [22,23,83], while ignoring the importance of ecosystem functions and ecosystem services (Biodiversity is necessary for the provision of ecosystem services, but more biodiversity will not necessarily deliver more ecosystem services. The provision of ecosystem services is influenced more by the ecological characteristics of the more general species than by the number of species [18].) for economic prosperity, sustainable development (Unsustainable use of ecosystems reduces their ability to deliver ecosystem services [96]. In The Netherlands this has been the case since about 1990. As a result, the supply of ecosystem services in The Netherlands can no longer meet all Dutch demand on this, which increases the dependence of the Dutch economy on natural capital abroad [97].) and human well-being [45,98-101]. Ecosystem functions and ecosystem services should therefore also be assessed and compensated [102]. Some authors therefore argue that multiple ecological, instrumental and noninstrumental values of social-ecological systems should all be taken into account in calculations [103]. However, the necessary broadening or integration of valuation systems that could facilitate this multidimensional value approach in nature compensation and habitat banking, is not or is hardly available yet $[18,103]$. Although many relevant studies have been conducted [79,101,102,104-106], generic indicators as a basis for workable valuation systems for economic and societal valuation of ecosystem services and functions are still missing. Furthermore, since what is not measurable is not compensated, nature compensation and habitat banking can lead to multiple losses and unsustainable results. These losses concern ecological, instrumental and noninstrumental values [88,103].

In line with these criticisms, researchers point out that economic logic disconnects nature conservation from its spatial, evolutionary, historical, social, and ethical context $[88,89,101]$ and that 
all in all moral responsibilities of man towards nature, biodiversity and a sustainable society get eroded [47,103,107-109]. To counteract this development, scientists point out that economic activity depends on and should therefore be embedded in self-organizing natural and social systems with awareness of limits to growth [107]. In this regard, social scientists argue that (i) the natural environment is socially and culturally constructed, meaning that problems in environmental and nature policy are always the result of such constructions $[86,91,99,100,110,111]$ and (ii) therefore a serious focus on relational values in research and social-environmental decision-making is needed. Relational values underpin meaningful relationships and responsibilities between individuals and societies, and also include sought-after human-nature relationships [45,46,100,112-114]. The underlying paradigm of sociological research (i.e., a holistic or integrated paradigm $[85,115]$ ) is less technocratic and reductionistic and takes more accounts of nonlinear interactions, subjectivity and motivations of people $[85,86,116-119]$.

Habitat banking, however, also offers opportunities and possibilities for solving the problems for nature and biodiversity and for sustainable development. Our design of habitat banking in the next section therefore takes into account the criticisms outlined above.

\section{Design of Habitat Banking in The Netherlands}

\subsection{Habitat Banking in the Field of Nature Compensation}

A way to address both socio-ecological uncertainties and the multitude of values associated with social-ecological systems could be to combine top-down and bottom-up knowledge in participatory stakeholder processes (e.g., focus groups, deliberation workshops) in order to arrive at transparent and responsible "compromise solutions" [103,120,121]. As we have already seen, these "compromise solutions" on an ecological, economic and social basis are considered relevant to achieving sustainable development. The results of top-down introduced reductionist-technocratic economic and ecological value calculations can guide the intended participating stakeholder processes. They should not be considered as absolute truths, but should be linked to socio-cultural and relational values from a specific bottom-up perspective.

Gorissen et al. [15] explain that the implementation of habitat banking to improve biodiversity, mandatory nature compensation and sustainable development in The Netherlands, requires a top-down process of an evolving governmental framework of instruments, (calculation) tools and protocols interacting with bottom-up integral area pilots, in which primarily market and society work together, as shown in Figure 3. The interaction between the top-down and bottom-up perspective is considered a process of socio-ecological learning.

As a first step in a process towards habitat banking, various parties argued in favor of experimenting with a system of voluntary compensation for the loss of biodiversity $[18,19,74,75]$. This is in order to minimize or limit the potential risks to nature and biodiversity, associated with the complexity of the legal, ecological, administrative and financial frameworks of mandatory nature compensation. In addition, as there are fewer legal restrictions in the domain of voluntary compensation, there are more opportunities to gain experience with habitat banking and the instruments and organization needed for this. Scientists in The Netherlands recommend starting with area pilots aimed at a broader application of habitat banking at a regional level. Private parties such as citizens and companies are willing to invest in nature, but so far, their interests have not been sufficiently exploited in practice $[15,122]$. 


\section{Government}

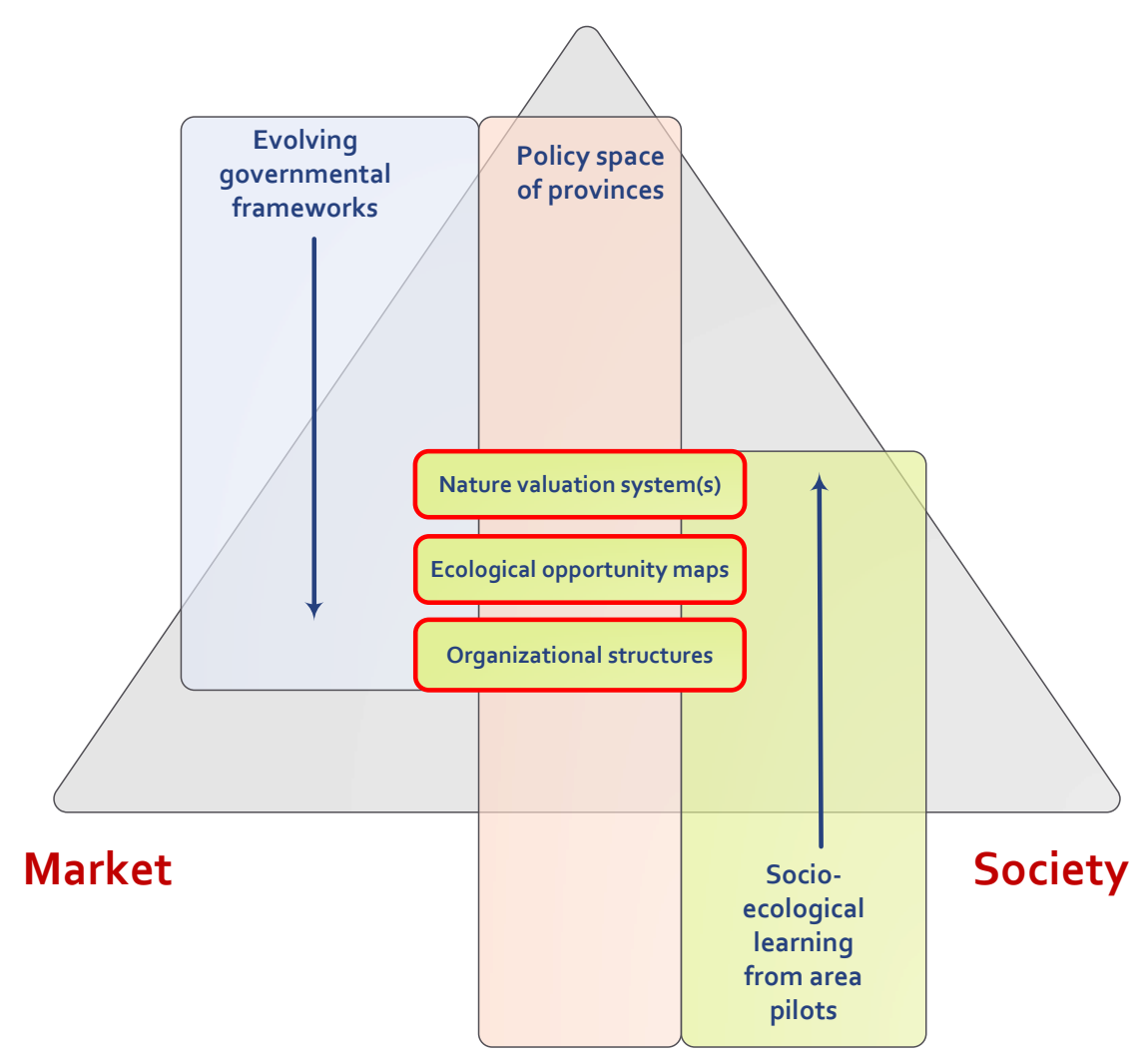

Figure 3. Top-down evolving governmental framework of required instruments and bottom-up socio-ecological learning from area pilots. The policy space of Dutch provinces is at the hinge point [15].

\subsection{Top-Down Evolving Governmental Frameworks on Economic and Ecological Values}

In order to start a habitat banking system in The Netherlands that ultimately has added value for both voluntary and mandatory nature compensation, at least the following instruments and frameworks should be in place $[15,18,31,34]$ :

1. nationally recognized nature valuation systems to validate (where we refer to "validation" in this article, other publications about habitat banking refer to "certification") the ecological value of (a) new nature and nature that is to be compensated, as well (b) the greening of landscapes in order to improve the quality of the living environment;

2. ecological opportunity maps that (a) help suppliers and demanders of biodiversity credits to make choices about where to implement which type of compensation, and (b) can facilitate companies with their area-specific choices, based on the importance of public support in their local environment and the desire to achieve compensation preferably as locally as possible; and

3. a national organizational structure, including (a) a central board as shown in Figure 1 for habitat banking to legally arrange trade in biodiversity credits, create tools and protocols, and supervise the functioning of habitat banking, and (b) a habitat bank that registers biodiversity credits, areas for which credits are registered and habitat responsibilities, providing insight into the potential supply and demand of biodiversity credits and financially monitoring the trade of biodiversity credits.

\subsection{Socio-Ecological Learning about Socio-Cultural and Relational Values in Bottom-Up Integral Area Pilots}

Provinces can play an important role in testing potential nature valuation systems, ecological opportunity maps and habitat banking organizations. They have the expertise to facilitate habitat 
banking experiments in integral area pilots that bring together opportunities for creating new nature (creating nature credits) and demand for nature compensation. They can bring individual interests of landowners and land users in line with collective interests of economic and nature development. In some provinces in The Netherlands, the possibilities of taking practical steps towards habitat banking have been investigated [25,122-124]. Gorissen et al. [15] (pp. 49-50) have elaborated the frameworks, outlines and preconditions for a successful implementation of such area pilots for habitat banking.

These pilots allow for organizational and social learning [125-135], and for sustainability-oriented innovation [107]. They thus enable the further development of best practices of the area pilots into a habitat banking system that will ultimately also have an added value in terms of mandatory nature compensation, in line with the principles of the BBOP Standard [22,23,83]. Based on scientific literature, we propose a learning process scheme for the further development of habitat banking in three phases, as shown in Figure 4.

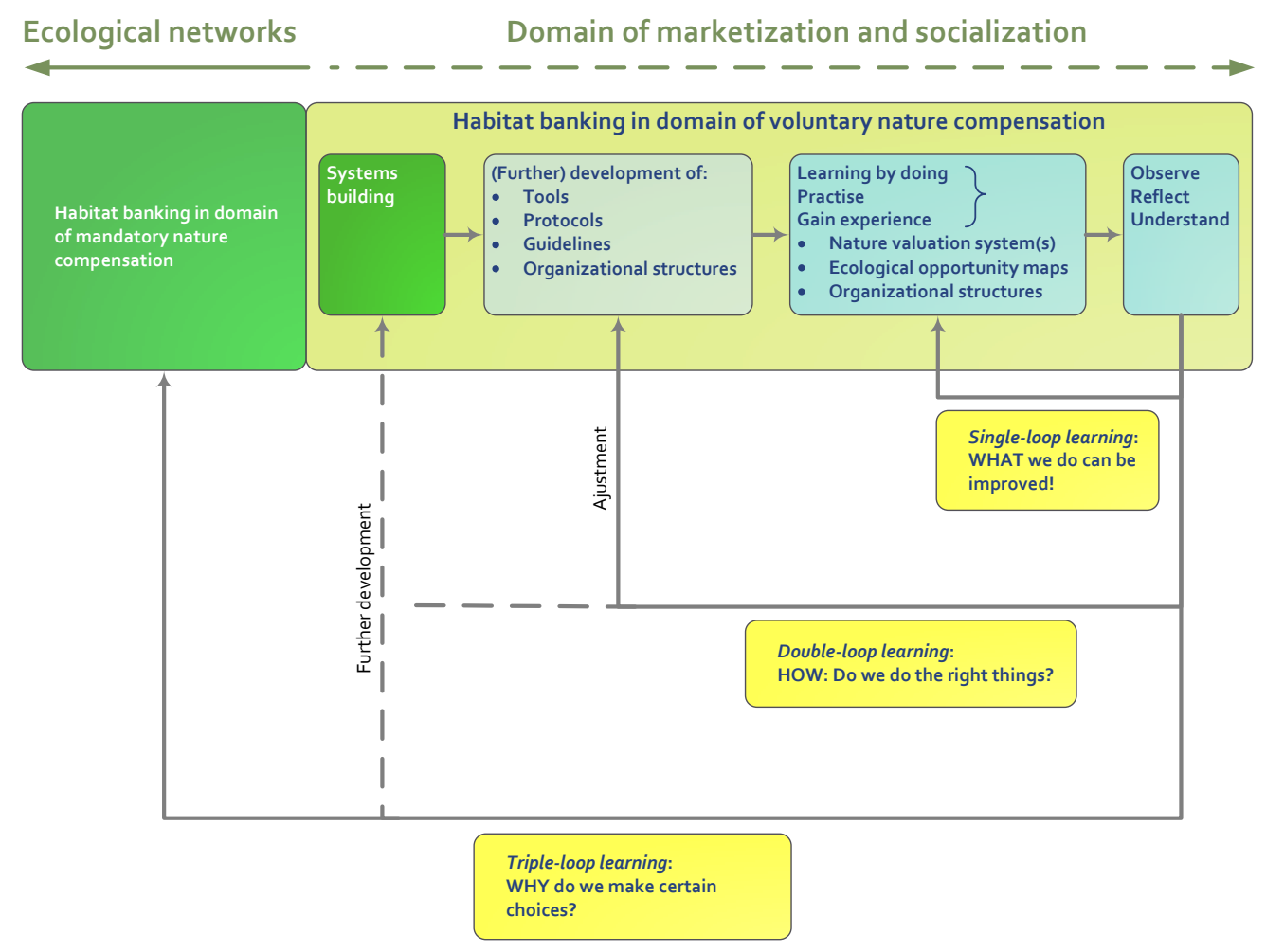

Figure 4. Further development of habitat banking through single-loop, double-loop and triple-loop learning [15].

These three learning phases can be referred to as follows:

1. Single-loop learning: habitat banking as an experiment. This learning cycle is about operational optimization and eco-efficiency, i.e., what we do can be improved: Do we do the things right? In other words, do we work effectively, or can things be improved? Single loop learning therefore means learning through the consequences of specific actions. In the case of habitat banking, this initially relates to the available nature valuation system(s), ecological opportunity maps and organizational structures.

2. Double-loop learning: further development of habitat banking for voluntary nature compensation. This is about organizational transformation, and the how: Do we do the right things? Do we work efficiently, or can we achieve our goal more easily by focusing (more) on other things? In double loop learning people reflect on the assumptions which underlie their actions. In habitat banking, double loop learning results in (further) developed tools, protocols, guidelines and organizational structures. 
3. Triple loop learning: habitat banking as a system, ultimately also for mandatory nature compensation. This learning cycle is about system building and societal change, i.e., the why: Why do we make certain choices? Only with this solid substantiation can habitat banking as a system have sufficient strength for a responsible further application in the context of mandatory nature compensation to deliver no net loss or net gain of biodiversity $[22,23,83]$, with use of the developed tools, protocols, guidelines, and organizational structures. Different parts of a habitat banking system can go through different learning cycles simultaneously [131].

The learning process described above is still fairly technocratic and reductionist. It is based on the predominant vision on habitat banking in scientific literature, where nature valuation systems, ecological opportunity maps and organizational structures are considered objective truths. This approach is associated with the risk that ultimately (i) personal commitments towards nature, narratives and constructs of connectedness with nature and the natural landscape will be eroded [47,59], and (ii) the development of a habitat banking system gets stuck in bureaucratic work processes and institutions that produce "more of the same" or "at most a better version of the same" [134]. Such work processes and institutions may thus gradually lose their democratic legitimacy. To counterbalance this development, it is crucial to organize the learning process on habitat banking in connection with the corresponding social and cultural context [86,136]. For a democratic development process of habitat banking, it is therefore vital that discursive practices include marginalized notions of nature and its values $[59,114]$ (p. 6; pp. 40-49). As a consequence, in order to prevent the development of a habitat banking system from stagnating, it is necessary to establish the learning process above in association with a cocreative learning process: a joint interaction process of social learning by doing. This socio-ecological learning process is accompanied by the development of horizontal social networks: dynamic, open and complex social systems on different scales, each with their own identity and value systems [134]. In the context of habitat banking, these horizontal social networks provide further insight into (i) the relationships and associated value systems between people and nature and between people themselves, (ii) the corresponding role of man towards nature of culturally reflexive stewardship [54] and indirect reciprocity [56], and (iii) the universal moral values in communities of indirect reciprocity [56]. Horizontal social networks that apply socio-ecological learning generate self-organizing social-ecological systems (SESs). In interaction with the organization of habitat banking, these SESs enforce an adaptive management of the approach and further development of habitat banking. Adaptive managers and decision-makers constantly monitor and integrate the right ecological, social and economic information into management, thus turning policy-making into an interdisciplinary, participatory and iterative process in which uncertainty is dealt with in a responsible manner $[81,107,137,138]$.

\section{Assessment of Nature Valuation Systems for Habitat Banking}

For the success of habitat banking, it is crucial to use ecologically justified and validated methods to determine the value of nature and biodiversity that is developed (credits), or that is lost (debits) [18,31,34]. Based on these validated credits and debits, choices can be substantiated aiming at nature-inclusive solutions, the extent of nature compensation and social support [15], as well as at the many other application areas mentioned in the literature [33].

A frequently asked question is how to monetize calculated nature values in order to facilitate trade between supply and demand of biodiversity credits. The findings with habitat banking in Germany, England and Sweden $[15,139,140]$ (p. 38, Annex 3) show a preference for valuation systems that express nature values in objective units, but not in monetary units (money). The monetary value of biodiversity credits (positive) and biodiversity debits (negative) arises from market forces and depends on specific local or regional circumstances (e.g., land prices and development costs).

The four nonmonetary nature valuation systems we assessed (1. [28]; 2. [18]; 3. [31,32]; and 4. [33]) (where we refer to "validation" in this article, other publications about habitat banking refer to "certification") can all be considered as primary valuation systems. (Primary systems are systems that 
are designed to calculate nature value; secondary systems can be used to calculate nature value, but are not primarily designed for this [33] (p.15).) They are all rooted in the mean species abundance (MSA) index and further refined for their use in practice. The mean species abundance index is an indicator of naturalness or biodiversity intactness. It is defined as the mean abundance of original species relative to their abundance in undisturbed ecosystems. An area with an MSA of $100 \%$ means a biodiversity that is similar to the natural situation. An MSA of $0 \%$ means a completely destructed ecosystem, with no original species remaining. MSA is similar to the biodiversity integrity index, the biodiversity intactness index (BII) and the living planet index (LPI) [141]. The GLOBIO team (i.e., a team of about 10 staff members at PBL charged with projects on international biodiversity and other topics such as biodiversity indicators, and goods and services [141]) emphasizes that MSA does not completely cover the complex biodiversity concept and that complementary indicators should be included, when used in extensive biodiversity assessments. MSA is an integrated indicator for measuring the current and future status of biodiversity in areas that request or offer nature credits [18]. In this context, the valuation methods examined are essentially based on the acreage of the lost or created nature area, the ecological quality and a weighting factor, based on rarity and trends of species or the habitat type they live in. In addition to the primary valuation systems, Jaspers et al. [33] consider the Red Lists as a secondary valuation system for assessing the effects of interventions on nature value and biodiversity. In combination with the primary systems, this secondary system can be used to bypass practical problems in the assessment. For example, when defining nature types or partly arbitrarily determination of the weighting factors per nature type. In such cases, biodiversity value can be directly linked to the current or future occurrence of Red List species or the rarity of species rather than via nature types. The occurrence of rare species or Red List species is indicative of quality, rarity and possible degree of threat. The combination of a primary valuation system with the Red Lists as a secondary valuation system integrates the species completeness and weighting score (rarity and threat) at the species level [15] (p. 41 and Annex 4, section E). We therefore consider the Red Lists also suitable for use in addition to primary valuation systems for further refinement at the scale of areas or area pilots.

The results of the assessment of the four primary nature valuation systems using the four assessment criteria of Section 2 (a. ecologically justified; b. workable; c. credible; and d. applicable) are shown in Table 1. Based on this assessment of nature valuation systems, we analyzed the question of their application areas and associated advantages and disadvantages in Table 2. We distinguish the following assessment scores in Tables 1 and 2:

= very positive/very appropriate.

* positive/appropriate.

- moderately/less appropriate.

- = limited/not appropriate.

$?=$ unclear

In general, our findings in Table 2 are as follows:

- The National Green Fund's nature valuation system [31,32] is the most suitable for mandatory nature compensation.

- The value system of the preliminary study on habitat banking [18] is most useful for area pilots on habitat banking with voluntary nature compensation.

- The PBL's valuation system [28] and the BEE platform's aggregated valuation system [33] are more or less in the middle between the two previous systems.

- The BEE platform's aggregated valuation system [33] is the most suitable for facilitating sustainable integrated area development, because it quickly and unambiguously shows the effects of various options for action in areas on nature, both inside and outside protected nature areas. 
- The PBL's valuation system [28], the value system of the preliminary study on habitat banking [18] and the BEE platform's aggregated valuation system [33] are all suitable for use in pilots on habitat banking with voluntary compensation.

- For area pilots on habitat banking with mandatory and voluntary compensation, all four assessed nature valuation systems can be used, possibly in combination in order be able to provide area-specific customization.

Finally, we would like to make the following comments on this study of nature valuation systems:

1. The concept of "biodiversity" should be seen as a discursive find of recent times [154] (p. 53), while the relationship between man and nature is already as old as humanity.

2. All nature valuation systems assessed here are based on the idea that the value of nature and biodiversity can be objectively calculated. However, as we have already seen, the idea of an objective truth about the value of nature and biodiversity does not exist, as all valuation processes are socially and culturally constructed. It is vital for the success of habitat banking to make this awareness operational in its work processes.

3. Environmental impact assessments and economic versus ecological value assessments have difficulty in capturing, in particular, socio-cultural values and underlying human and moral values [54,155]. As a result of all this, governments, policy makers and nongovernmental organizations struggle with the question of how communities can be effectively involved in environmental decision-making. Participatory processes in bottom-up area pilot projects can contribute to solving this problem. 
Table 1. Global assessment of four mean species abundance (MSA)-based primary nature valuation systems against criteria a-d.

\begin{tabular}{|c|c|c|c|c|c|}
\hline Criteria $\rightarrow$ Valuation System $\downarrow$ & $\begin{array}{l}\text { a. Ecologically } \\
\text { Justified }\end{array}$ & $\begin{array}{c}\text { b. Workable } \\
\text { Uncomplicated Payable }\end{array}$ & $\begin{array}{l}\text { c. Credible Transparent } \\
\text { Objective Social Support }\end{array}$ & d. Applicable & Main Remarks/Concerns \\
\hline $\begin{array}{l}\text { Environmental Assessment } \\
\text { Agency of The Netherlands } \\
\text { (PBL) [28] }\end{array}$ & $*$ & $\begin{array}{l}\mathrm{U} \\
\mathrm{P} ?\end{array}$ & $\begin{array}{l}\mathrm{T} \\
\mathrm{O} \\
\mathrm{S}\end{array}$ & $\bullet$ & $\begin{array}{l}\text { - Developed primarily for use in sustainable integrated area development and } \\
\text { cost benefit analysis (CBA). } \\
\text { - Calculates relative decrease or increase in nature value. } \\
\text { As a fixed frame of reference for the societal valuation of calculated nature points } \\
\text { is missing in this valuation system, this result does not provide information on } \\
\text { the actual value of nature in points or units with more general validity. } \\
\text { - Nature points or units and mean species abundance (MSA) according to the PBL } \\
\text { system provide a scientific basis for the objective determination of the quality of } \\
\text { nature, but underlying data are often lacking. } \\
\text { Required use of expert judgement as well as the availability of effect forecasting } \\
\text { models for certain types of nature are unfavorable in relation to objectivity } \\
\text { and applicability. } \\
\text { Various uncertainties have been identified in the determination of nature points } \\
\text { based on the PBL system: i) the exact content of measures to be assessed; ii) } \\
\text { future (autonomous) developments; iii) the information and models used to } \\
\text { assess the effects of autonomous developments and measures [30]. (These } \\
\text { concerns of Van Gaalen et al. [30] did not only apply to the PBL system, but also } \\
\text { to the other valuation systems the authors investigated [15].) } \\
\text { The application of weighting factors could be further improved [30]. }\end{array}$ \\
\hline $\begin{array}{l}\text { Preliminary study on habitat } \\
\text { banking [18]. }\end{array}$ & 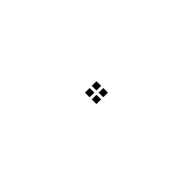 & $\begin{array}{l}\mathrm{U} \\
\mathrm{P} ?\end{array}$ & $\begin{array}{l}\mathrm{T} \\
\mathrm{O} \\
\mathrm{S}\end{array}$ & For habitat banking: & $\begin{array}{l}\text { - Developed primarily for application for flexible compensation on a } \\
\text { voluntary basis. } \\
\text { - Same remarks for nature quality determination as for PBL system. } \\
\text { - Simply applicable, especially due to the lack of a weighting factor. } \\
\text { voluntefory compenensation. }\end{array}$ \\
\hline $\begin{array}{l}\text { Instrument for Nature Points of } \\
\text { The Netherlands' National } \\
\text { Green Fund [31,32] }\end{array}$ & $*$ & $\mathrm{P}$ & $\begin{array}{c}\mathrm{T} \\
\mathrm{O} \\
\mathrm{S}\end{array}$ & For habitat banking: & $\begin{array}{l}\text { - Developed primarily for application in relation to mandatory compensation } \\
\text { and offsetting. } \\
\text { - Limited depending on expert judgement. } \\
\text { - Method of determining future nature quality is not clear. } \\
\text { Policy status is given too much emphasis in the calculation (compared to, for } \\
\text { example, the criterium "ecological quality"). Jaspers et al. [33] recommended to } \\
\text { bring the weighting factors of the Nationaal Groenfonds \& Van } \\
\text { Groenendael [31,32] more in line with the scale of the PBL system [28] and made } \\
\text { proposals to that effect [15] (Appendix 4, pp. 95-105). } \\
\text { As a fixed frame of reference for the societal valuation of calculated nature } \\
\text { points is missing in this valuation system, it cannot make clear the actual nature } \\
\text { value in points or units with more general validity. } \\
\text { - Less suitable for use in habitat banking in voluntary compensation. }\end{array}$ \\
\hline
\end{tabular}


Table 1. Cont.

\begin{tabular}{llcll}
\hline Criteria $\rightarrow$ Valuation System $\downarrow$ & $\begin{array}{c}\text { a. Ecologically } \\
\text { Justified }\end{array}$ & $\begin{array}{c}\text { b. Workable } \\
\text { Uncomplicated Payable }\end{array}$ & $\begin{array}{c}\text { c. Credible Transparent } \\
\text { Objective Social Support }\end{array}$ & d. Applicable
\end{tabular}

Main Remarks/Concerns

- Developed primarily to determine the added value of nature-inclusive projects for nature quality.

- Conversely, it is also aimed at promoting nature-inclusive projects and increasing social support.

- By choosing to calculate the quality of nature using species lists from the Manual of Nature Target Types [142] Jaspers et al. [33] ignored the more recent system of the Natura 2000 habitat types [143], the Vegetation of

Aggregated nature valuation system of the Platform BEE (Biodiversity-EcosystemsEconomy) [33] (Platform BEE was a "green deal" of the Dutch employers' organization-the Confederation of Netherlands Industry and Employers

(VNO-NCW) and the nature organization-the Dutch national committee of the International Union for Conservation of Nature (IUCN Netherlands) over the years 2012-2016. These organizations worked together with corporat businesses, nature and environmental organizations, development cooperation and Wageningen "niversity, and biodiversity and ecosys" of and (ii) "inclusive green and (ii) "inclusive green

Dutch Ministry of Economic

Affairs, the two initiating organizations form the platform's secretariat [76])
The Netherlands [144-149], and the Nature and Landscape Index [150].

- Independently of this, we consider the premise of Jaspers et al. [33] that the species lists in the Manual of Nature Target Types [142] have been fully and nationally validated, as questionable.

- Nature quality should be determined more on the basis of habitat quality than proposed by Jaspers et al. [33] and less on the species lists of Bal et al. [142] After all, species present or to be developed depend on the habitat quality and thus are the result of that. Since this requires more expert judgement, we recommend further optimization based in particular on the criteria a) ecologically justified; b) workable and c) credible.

- In determining the current and future situation, Jaspers et al. [33] assume different groups of species. As a result, the situation before and after the intervention are not comparable. In this regard, we recommend (i) to assess the current and future situation on the basis of the same groups of species, in order to establish the baseline situation; and (ii) to use the same groups of species as indicators to predict the future situation and to measure developments periodically after the intervention.

- For certain types of nature, plants are excluded from the assessment. By contrast we recommend using plants as a basis for the assessment of all types of nature.

- For certain types of nature, the assessment of the species group of plants Database Flora and Fauna (NDFF) [151] are not fully used.

- As a point for improvement, we therefore recommend using the data from the National Vegetation Database (LVD) $[152,153]$ in addition to the NDFF

- In line with this, we consider ecological opportunity maps as a logical next step.

- Another recommendation is to further develop the frame of reference Nature Target Types [142] into

- The selection of species groups with a limited versus a large number of reference species leads directly to a relatively low-quality versus a relatively high-quality score. This can give a distorted picture that should be corrected.

- As a fixed frame of reference for the societal valuation of calculated nature points is missing in this valuation system, this result does not provide information on the actual value of nature in points or units with more general validity.

- (System) optimizations recommended by Jaspers et al. [33] should actually 
Table 2. The usefulness of four MSA-based primary valuation systems for applications at regional and national scale levels.

\begin{tabular}{|c|c|c|c|c|}
\hline $\begin{array}{c}\text { Application } \rightarrow \text { Valuation } \\
\text { System } \downarrow\end{array}$ & $\begin{array}{l}\text { Sustainable Area } \\
\text { Development }\end{array}$ & $\begin{array}{l}\text { Pilots Habitat-Banking with } \\
\text { Voluntary Compensation }\end{array}$ & Mandatory Compensation & Key Remarks, Pros and Cons \\
\hline $\begin{array}{l}\text { Netherlands Environmental } \\
\text { Assessment Agency (PBL) [28] }\end{array}$ & $*$ & $*$ & $*$ & $\begin{array}{l}\text { - Widely applicable, but not always optimal in } \\
\text { specific situations. }\end{array}$ \\
\hline $\begin{array}{l}\text { Preliminary study habitat } \\
\text { banking [18]. }\end{array}$ & - & 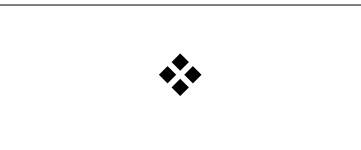 & - & $\begin{array}{l}\text { - There is a risk that rare nature is } \\
\text { compensated with less rare nature. } \\
\text { - In the field of voluntary compensation, this } \\
\text { risk is limited. }\end{array}$ \\
\hline $\begin{array}{l}\text { Netherlands National Green } \\
\text { Fund [31,32] }\end{array}$ & $\bullet$ & - & 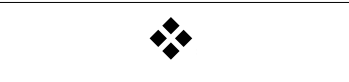 & $\begin{array}{l}\text { - Centralization of government goals limits } \\
\text { the applicability. }\end{array}$ \\
\hline $\begin{array}{l}\text { Biodiversity-Ecosystems-Economy } \\
\text { Platform (BEE Platform) [33] }\end{array}$ & $\forall$ & $*$ & $*$ & $\begin{array}{l}\text { - Compensation on the basis of nature points } \\
\text { can be a fallback option if compensation with } \\
\text { the same type of nature is not possible. It } \\
\text { should be made an additional condition that } \\
\text { only compensation by a nature type with an } \\
\text { equal or higher weighting factor is possible. } \\
\text { - Stimulates nature-inclusive thinking and } \\
\text { acting, thus facilitating sustainable } \\
\text { area development. } \\
\text { Featured(system)-optimizations are not } \\
\text { yet realized. }\end{array}$ \\
\hline
\end{tabular}




\section{Ecological Opportunity Maps: Search Tools for Ecological and Economic Developments}

In addition to one or more nature valuation systems as an objective supporting instrument for habitat banking, ecological opportunity maps are required [34] (pp. 73-75). Such ecological opportunity maps are geographical maps that show the suitability of locations and areas for species and habitat types. These maps can therefore facilitate suppliers and buyers of biodiversity credits to make choices about where they want to introduce which compensation. Ecological opportunity maps are generated by linking distribution data of species and plant communities (possibly aggregated into habitat types or nature target types) to various thematic maps (including geomorphology, soil, water management, climate and land use) using GIS [156]. Ecological opportunity maps can be combined with other map layers, based on, for example, the hotspot monitor [157], Atlas Natural Capital [158] or research into multifunctional green space and the importance of nature in the context of the Atlas for municipalities [159]. For the background of working with ecological opportunity maps, we refer to Appendix A.

Ecological opportunity maps can be used for two purposes, which provide information relevant to the development of mandatory and voluntary compensation plans:

1. optimization of the choice of a planning location by identifying risks and reducing the research burden for initiators; and

2. finding a suitable compensation location and calculating the net gain of nature.

In Appendix A we further discuss working with ecological opportunity maps (Appendix A.1), methods for creating ecological opportunity maps (Appendix A.2), and the use of ecological opportunity maps for planning considerations (Appendix A.3).

\section{Organizational Structures for Habitat Banking in The Netherlands}

In principle, three main forms of organization are suitable for the coordination of transactions in the context of habitat banking and sustainable development: (1) pure markets characterized by a demand, a supply, a transaction of (virtual) goods or services and a price (e.g., the Western European wood market or stock markets); (2) hierarchies, with a focus mainly on command and control (e.g., the EU Emissions Trading System (EU ETS) [160]); or (3) hybrid forms, which combine features of markets and hierarchies (e.g., Apple Inc. with its independent dealer network, or more specifically, the wetland mitigation banking system in Florida-the Regulatory In lieu fee and Bank Information Tracking System (RIBITS) [24]). Scientific research has shown that a hybrid form of organization is most suitable for habitat banking. This means the market characteristics of a habitat banking system should allow a certain degree of autonomy and self-adjustment between developers of nature credits and habitat bankers, but only once the number of allocated or required credits has been determined by regulators $[19,24,90]$. Oversimplification of a habitat banking system as just "a market" has led to much criticism of this compensation for nature and biodiversity [24]. For creating confidence in a habitat banking system, it is essential that regulators (i) are independent, (ii) have the necessary expertise and experience (with regard to nature conservation policy, land use policy and planning regulations, environmental legislation, business law and financial administration), (iii) are adequately funded and have sufficient staffing capacity to work effectively and within reasonable time limits, and (iv) can be controlled, with publicly available audits of their activities and decisions [19].

Research into habitat banking in The Netherlands has also shown that societal confidence in the system, as well as users' confidence in each other are essential to its success. These users can include companies, private landowners, land management organizations, banking institutions and possibly public authorities. Habitat banking in The Netherlands is regarded a feasible option for voluntary compensation if its governance and management are designed independently, transparently, cost-effectively and efficiently $[18,33]$. To this end, the following elements are considered important in the context of a regulatory role within an organizational structure for habitat banking in The Netherlands: 1) a central board for habitat banking and 2) a habitat bank $[18,122]$. This is in line with the approach 
in many other countries $[19,20,90,139,161]$ and also essentially corresponds to the organizational structure that emerged from the investigations of Blom et al. [26] on how to set up a trading system for biodiversity in Europe. Combining the two instances in one organization would be simpler and potentially save costs but is not recommended. It would undermine the credibility of habitat banking because an organization that is solely controlled itself does not inspire confidence. In addition, the tasks of a central board for habitat banking and a habitat bank are so different that there is no added value in terms of both content and financial aspects of the association in a single organization [18].

In order to be able to start habitat banking against the background of socio-ecological learning in Dutch area pilots, a decision is required on (1) the establishment or designation of both a central board for habitat banking and a habitat bank, and (2) validation of the value and quantity of nature credits and debits $[22,23,83]$. For an explanation of the character and tasks of both organizations, we refer to, among others, De Bie and Warmenhoven [18] (pp. 53-56) and Gorissen et al. [15] (pp. 44-48). For the first period until the viability of habitat banking has been proven in practice, it is recommended to connect with existing organizations for the role of both organizations [18]. We investigated which existing organizations might be suitable for the role of both organizations during an initial phase of learning and experimenting. The results are shown in Tables 3 and 4 respectively.

Finally, we would like to point out that organizations for a first role in habitat banking should aim at (i) supporting participatory decision-making processes in bottom-up area pilot projects and (ii) providing adequate guidance for these processes. Of course, they must be prevented from developing power cultures with maintenance of their own organization as main objective.

Table 3. Overview (not exhaustive) of the advantages and disadvantages of candidates for the role of the central board for habitat banking in an initial phase. (The analysis of the advantages and disadvantages of the National Green Fund has been adopted from De Bie and Warmenhoven [18].).

\begin{tabular}{|c|c|c|}
\hline Organization & Advantages & Disadvantages \\
\hline $\begin{array}{l}\text { Commission for } \\
\text { Environmental Impact } \\
\text { Assessment [162] }\end{array}$ & $\begin{array}{l}\text { Well acquainted with the system and methodology } \\
\text { of prevention, mitigation and compensation. } \\
\text { Compensation is the final piece of impact } \\
\text { assessment and is therefore in line with } \\
\text { environmental impact reporting. } \\
\text { - High level of knowledge and experience about } \\
\text { monitoring and reporting on } \\
\text { environmental measures. } \\
\text { - Familiar with a wide range of companies and } \\
\text { their activities. }\end{array}$ & $\begin{array}{l}\text { - Unknown with implementation of } \\
\text { nature compensation. } \\
\text { Less familiar with biodiversity, } \\
\text { habitat types and the like; more } \\
\text { focused on environmental impacts. } \\
\text { This is an operational task that is } \\
\text { not fully compatible with the } \\
\text { Commission's completely } \\
\text { independent role in Environmental } \\
\text { Impact Reporting. }\end{array}$ \\
\hline $\begin{array}{l}\text { National Green } \\
\text { Fund [163] }\end{array}$ & $\begin{array}{l}\text { Well aware of the methodology of mandatory } \\
\text { nature compensation. } \\
\text { Extensive experience in the implementation of the } \\
\text { mandatory nature compensation. }\end{array}$ & $\begin{array}{l}\text { - Unfamiliar with environmental } \\
\text { management by and in companies. } \\
\text { Is not unprejudiced about the } \\
\text { implementation of voluntary } \\
\text { compensation due to close } \\
\text { involvement with } \\
\text { mandatory compensation. }\end{array}$ \\
\hline $\begin{array}{l}\text { IUCN NL [77], in } \\
\text { continuation of Platform } \\
\text { BEE [76] }\end{array}$ & $\begin{array}{l}\text { - Working at the interface of companies and } \\
\text { natural capital. } \\
\text { Focuses on three themes: (1) green international } \\
\text { cooperation; (2) greening the business sector; } \\
\text { (3) restoration and conservation of nature. } \\
\text { Is broadly composed of stakeholders from the } \\
\text { business community and stakeholders with a } \\
\text { background in nature and environmental } \\
\text { protection and biodiversity (including NGOs). } \\
\text { Has knowledge of biodiversity measurement } \\
\text { methods, the Natural Capital Protocol and } \\
\text { Sector Guides. }\end{array}$ & $\begin{array}{l}\text { It is not yet known whether } \\
\text { IUCN-NL is open to extending its } \\
\text { range of duties with tasks } \\
\text { associated with a central board for } \\
\text { habitat banking. }\end{array}$ \\
\hline
\end{tabular}


Table 3. Cont.

Organization Advantages Disadvantages

Another organization as a possible candidate for the role of central board for habitat banking in the future is the Metta Standard and Metta Index Organization [164] (see below). The Metta Standard and Index organization enables the quantification of the environmental impacts of a company, and facilitates the compensation of those impacts, after the company has mitigated them to the extent possible internally. This means that the Metta organization is currently mainly a user of habitat banking. As a result, the Metta organization is not yet equally eligible as a candidate for the role of central board for habitat banking. However, if the Metta organization continues to develop in this direction, it will become an interesting candidate for this.

Metta Standard and Metta Index organization [164]
- Has developed the Metta quality mark for impact-neutral entrepreneurship.

- Has developed quantification rules for compensation

- Beyond biodiversity, which means that the Metta organization focuses not only on biodiversity, but also on other environmental impacts of companies, such as the use of natural resources, water and energy, land use and space occupancy, greenhouse gases and other emissions to the atmosphere, waste, and noise and light pollution.

- Has experience in doing assessments at companies and determining the need for compensation.

- Has experience with the mitigation ladder in relation to the ecological footprint of companies.

- Offers the necessary compensation through projects.

- Great expertise in the field of standardization and auditing.

Table 4. Overview (not exhaustive) of the advantages and disadvantages of candidates for the role of the habitat bank in an initial phase. (The analysis of the advantages and disadvantages of the National Green Fund has been adopted from De Bie \& Warmenhoven [18].).

\begin{tabular}{|c|c|c|}
\hline Organization & Advantages & Disadvantages \\
\hline National Green Fund [163] & $\begin{array}{l}\text { - Well aware of the methodology of } \\
\text { mandatory nature compensation. } \\
\text { Extensive experience in the } \\
\text { implementation of the mandatory } \\
\text { nature compensation. }\end{array}$ & $\begin{array}{l}\text { A lot of money paid to the Green } \\
\text { Fund for mandatory compensation } \\
\text { has not yet been spent. }\end{array}$ \\
\hline Face the Future [165] & $\begin{array}{l}\text { Experience with trading of } \\
\mathrm{CO}_{2} \text {-credits and forest protocols; } \\
\text { recent expansion of expertise with } \\
\text { agriculture and agroforestry. } \\
\text { Experience with ecosystems and } \\
\text { ecosystem services. }\end{array}$ & $\begin{array}{l}\text { - No experience with } \\
\text { nature compensation. }\end{array}$ \\
\hline $\begin{array}{l}\text { Netherlands Enterprise Agency } \\
\text { (Rijksdienst voor Ondernemend } \\
\text { Nederland: RVO) [166] }\end{array}$ & $\begin{array}{l}\text { Experience with Green Certificates } \\
\text { for banks. }\end{array}$ & $\begin{array}{l}\text { - As a government agency } \\
\text { connected with the government. }\end{array}$ \\
\hline $\begin{array}{l}\text { Forest and Nature Compensation } \\
\text { Foundation [167] }\end{array}$ & $\begin{array}{l}\text { - Well aware of the methodology of } \\
\text { mandatory nature compensation. } \\
\text { Extensive experience in the } \\
\text { implementation of the mandatory } \\
\text { nature compensation. }\end{array}$ & $\begin{array}{l}\text { Initiative is only a few years old } \\
\text { (foundation was established in } \\
\text { 2012). If this continues to develop } \\
\text { well, we see no disadvantages for } \\
\text { the time being. }\end{array}$ \\
\hline $\begin{array}{l}\text { Organization in the field of } \\
\text { stewardship and area } \\
\text { development }\end{array}$ & $\begin{array}{l}\text { Informed about forest and nature } \\
\text { compensation and area development. }\end{array}$ & $\begin{array}{l}\text { - We see no disadvantages for the } \\
\text { time being. }\end{array}$ \\
\hline $\begin{array}{l}\text { Bank that invests in sustainable } \\
\text { businesses and projects }\end{array}$ & $\begin{array}{l}\text { Experience in realizing financial } \\
\text { returns with respect for nature and } \\
\text { climate, for example green projects } \\
\text { (green energy, nature and } \\
\text { sustainable building), environmental } \\
\text { and water technology, organic } \\
\text { farming and natural food. }\end{array}$ & $\begin{array}{l}\text { - No experience with } \\
\text { nature compensation. }\end{array}$ \\
\hline
\end{tabular}




\section{Discussion}

Habitat banking is not undisputed. And it is still true that "facts are uncertain, values in dispute, stakes high and decisions urgent" [120,168]. In view of the substantial decline in nature and biodiversity, this statement calls for measures that can contribute to solutions for nature compensation and sustainable development. It is actually very clear that a healthy economy should be embedded in a healthy ecology and society [107], but how is this translated into adequate action perspectives? Does it make any sense at all to continue to consider nature conservation in conjunction with compensation for what will be destroyed by continued economic development? How can the interests of stakeholders, such as developers, nature conservation experts, businesses, citizens and habitat bankers, be involved in negotiation and decision-making processes in such a way that they do not subsequently pursue their own interests through protest actions or legal proceedings? Furthermore, what about the obvious conflicts of interest between different stakeholders? As long as there are no supported answers to these and similar questions, indicating that conflicts of interest are not being resolved but avoided, destructive compromises and unsustainable solutions are implicitly accepted, while explicitly dealing with them opens ways to constructive and sustainable solutions [89]. Actually, starting with habitat banking in practice, offers opportunities to explicitly ask and answer these questions.

Nature compensation and habitat banking are, in principle, technocratic systems to support private investment in conservation and market-based approaches to halt biodiversity loss. In at least a number of European countries, the rise of these systems in the current neoliberal era coincides with budget cuts in nature policy, the increasing commodification of nonhuman nature and the ongoing deregulation of environmental legislation [95]. The Netherlands also belongs to these countries [169]. In this regard, Apostolopoulou and Adams [95] argue that public attention to the dialectic of "un-green and green grabbing" ("un-green grabbing" is defined as the current neoliberal process of intensifying the exploitation of protected natural areas [95]) in society is paramount. This is because neoliberal logic and practices (i) ultimately act as a catalyst for the further degradation of nature and biodiversity; (ii) have to a large extent been able to motivate the state apparatus to develop into an entrepreneurial entity of the capital, and (iii) have radically changed our theoretical and political understanding of people's social relationship with nature, while (iv) advocates of the resulting capitalist expansion themselves imply contradictory normative assumptions about nature and biodiversity. In the context of "un-green and green grabbing", it is indeed not inconceivable that habitat banking will be misused by capitalist expansion. However, it can also provide a unique opportunity to explicitly consider contemporary nature conservation in relation to the human-nature relationship: extrapolation of its recent history to the future, ethical motives and moral responsibilities to nature or their loss over time, scientific challenges and political implications [89].

Nature policy in former times was almost exclusively legitimized by the intrinsic value of nature $[39,170]$, which means that nature conservation initially was a normative endeavor [171]. This justification for nature conservation is not widely acknowledged and still remains highly controversial [172], partly because it proved very difficult for people to understand and discuss nature's intrinsic value and its philosophical implications [173] (p. 153). Moreover, the notion of intrinsic value does not seem to motivate most people to behave in a way that is essential for nature conservation and sustainable development [46,174]. Conservationists should therefore define their new mission for the 21th century [171]. Perhaps relational values, further investigated within the frame of habitat banking, can help to find the way back to lost ethical motives and moral responsibilities to nature. Relational values can play a key role in framing and facilitating discussions in participatory decision-making processes aimed at linking environmental changes to physical and to nonmaterial human values, thereby contributing to the re-evaluation of conservation policy [170] (p. 8). This learning process could ultimately result in a contemporary innovation of the human-nature relationship based on (i) equivalence, (ii) a vision of humanity as part of nature, and (iii) a role of people towards nature grounded in culturally reflexive stewardship [54] and indirect reciprocity [56]. In this respect again, habitat banking can be misused by adapting it to the extrinsic values of mainly market players, but it 
can also contribute to reposition relational values in society, thereby helping to bridge the growing gap with underlying human and moral values. A multiple as well as multilayered value system for application in social-ecological systems $[82,175,176]$ at regional area level could help prevent misuse of habitat banking.

\section{Conclusions}

We conclude that habitat banking has added value for biodiversity and sustainable development, since this trading system of nature values (nature credits) (i) provides space for economic and social developments, while at the same time creating opportunities for developing new nature; (ii) offers new action perspectives to societal parties who want to deal with or make more targeted investments in nature development, thereby creating a more socially and ecologically responsible living environment; (iii) supports choices and decisions by stakeholders with ecologically justified, workable and trustworthy instruments and frameworks; (iv) offers a starting point for new financial mechanisms and business models for nature development and conservation, making the nature sector less dependent on government grants; (v) frees nature policy from excessive detailing and technocracy and the associated dependence on expert judgement; and (vi) ultimately also leads to an improvement of mandatory nature compensation. However, these conclusions are not undisputed. The controversy surrounding habitat banking can be traced back to an expected side effect in current neoliberal contexts in the Western world, that habitat banking will mainly lead to a further polarization between ecological values (planet) and economic values (profit), whereby social and cultural perspectives and values of nature (people) are pushed into the background. The added value of habitat banking, though, is not twofold but triple in principle: (1) people: social and societal, (2) planet: governmental and political, and (3) profit: financial and economic. In short, socio-cultural and social values, and ultimately people's ethical and moral values towards nature and biodiversity, require more attention in habitat banking. To this end, it is important to realize that nature valuation processes are socially and culturally constructed and, as a consequence, to launch habitat banking in conjunction with socio-ecological learning processes, which develop towards the application of multiple and multi-layered valuation approaches. In this context, a better understanding of relational values, which support (i) meaningful relationships and responsibilities between individuals in companies and society, (ii) relationships with and between associated societal institutions, and eventually (iii) the human-nature relationship, could also contribute to the inclusion of socio-cultural and social values within habitat banking and could ultimately restore the loss in current time of people's moral values towards nature.

To actually realize the added value of habitat banking for The Netherlands, we conclude that it is important to start small with habitat banking, initially (i) within bottom-up regional integral area pilots (ii) in the domain of voluntary nature compensation, and (iii) using participatory decision-making. This is in order to (1) minimize or limit the potential risks to nature and biodiversity (2) while at the same time increasing societal confidence, (3) be able to create a context of learning and experimentation and ultimately generate socio-ecological learning en route to social-ecological systems (SESs), and (4) be in a position to involve the widest possible range of relevant stakeholders of these areas with their belonging value systems. Thereby, it is recommended that the results of reductionist-technocratic economic and ecological value calculations should ultimately not be used as objective truths, but as input for the considerations about the multiple values of nature with regards to habitat banking in specific participatory area processes. This approach should enable the owners and users of those areas to gain a more decisive say in comparison with institutions and businesses, which can contribute to the democratic legitimacy of habitat banking and ultimately also of mandatory nature compensation. Over time, habitat banking thus helps to discover the significance of a contemporary human-nature relationship based on equivalence, a vision of humanity as part of nature, and a role of people towards nature grounded on culturally reflexive stewardship and indirect reciprocity. In short, habitat banking contributes to the further development of social-ecological systems. 
In all of this, based on our findings we consider it important to conduct extensive additional scientific research aimed at further collection and analysis of empirical data. As the success of habitat banking is context-dependent, this actually applies to all aspects of habitat banking we investigated for this article. Guidance of integral area pilots from the scientific community is in any case also important in this context. Furthermore, it would be interesting to conduct additional scientific research on the basis of more specific research questions, derived from relevant theories (e.g., institutional theories and supplementary learning theories).

Author Contributions: Conceptualization, M.M.J.G., C.M.v.d.H. and J.H.J.S.; methodology, M.M.J.G., C.M.v.d.H., and J.H.J.S.; validation, M.M.J.G. and J.H.J.S.; investigation, M.M.J.G.; resources, M.M.J.G. and J.H.J.S.; data curation, M.M.J.G.; writing—original draft preparation, M.M.J.G.; writing—review and editing, M.M.J.G., C.M.v.d.H. and J.H.J.S.; visualization, M.M.J.G.; supervision, M.M.J.G., C.M.v.d.H. and J.H.J.S.; project administration, M.M.J.G. All authors have read and agreed to the published version of the manuscript.

Funding: This research received no external funding.

Acknowledgments: We would like to thank Stephan Hennekens (Wageningen Environmental Research) for his help with our research into ecological opportunity maps, and Arjan Ruijs (former researcher of PBL Netherlands Environmental Assessment Agency) for his involvement during the early stages of this research, as well as for his critical review of the text. We also thank Steven de Bie (Conservation Consultancy and partner at De Gemeynt) and Jan van Groenendael (emeritus professor at Radboud University) for their help, and their tips and suggestions in the initial phase of the research. Finally, we are indebted to the Dutch province of Limburg, which has made manpower available to carry out this research and commissioned the survey among citizens and businesses in Limburg in 2015.

Conflicts of Interest: The authors declare no conflict of interest.

\section{Appendix A. Ecological Opportunity Maps}

\section{Appendix A.1. Working with Ecological Opportunity Maps in General}

Ecological opportunity maps of species and plant communities provide insight into the probability that a species or plant community could occur in an area of which no current observations are known. These maps also show whether a species may be more abundant than is apparent from the current known observations, in particular as stated in the National Flora and Fauna Database (NDFF) [151]. Ecological opportunity maps are an important tool for including biodiversity in planning decisions in a responsible way.

\section{Appendix A.2. Methods for Creating Ecological Opportunity Maps}

There are various methods for generating ecological opportunity maps. Two methods are discussed below: (1) a method for drawing up species opportunity maps (Appendix A.2.1) and (2) a method for determining plant community opportunities (Appendix A.2.2).

\section{Appendix A.2.1. Species Opportunity Maps}

On behalf of the Dutch Nature Data Authority, SOVON has made opportunity maps for a number of critical animal species and plant species in 2013 [177]. For this purpose, spatial static models were used, in which both presence and absence data of species are included. Information on absence is just as important as information on the presence of species and both types of data therefore play an important role in spatial modelling. In addition, information on land use and other environmental characteristics is used for modelling. This information is needed to describe relationships in statistical models between the observations and the environmental characteristics. These relationships are then used to predict the expected occurrence in The Netherlands (at the level of square kilometers). The makers of the ecological opportunity maps have drawn up a large set of environmental characteristics per square kilometer. A total of 323 environmental variables were used for the modelling with information on, among other things, land use, soil, groundwater level, crops, forest composition and water types. In order to avoid accidental connections and to speed up the modelling process, preselections were made from the total 
set of variables of species of agricultural land, semi-open landscape, buildings, nature, forest and water. As a result, the number of variables offered per species was limited to 70-110 [156].

On the website of the NDFF you can find an overview of the species for which opportunity cards are available [178]. Ecological opportunity maps have been drawn up for some fifty species, ranging from plant species to dragonflies, fish, reptiles, amphibians, butterflies, mammals and an invertebrate species.

Appendix A.2.2. Opportunity Maps for Plant Communities

A different method is used to generate opportunity maps for plant communities. As with species, the probability of a certain plant community occurring is calculated at the scale of square kilometers. Contrary to the approach for species, no use is made of observations about plant communities. An observation of a plant community concerns an analysis of the vegetation based on its species composition (i.e., vegetation recordings), which is assigned to a plant community either manually or automatically. What is used to generate opportunity maps for plant communities is, on the one hand, the floristic composition of a plant community in the form of a so-called synoptic table as displayed in Figure A1, and on the other hand, the occurrence of plant species in The Netherlands on the scale of square kilometers. For the time being, the information on the occurrence of plant species is based on an older version of FLORBASE [179]. At present, the distribution data is stored in the NDFF [151]. The advantage of using the floristic data is that for a large number of species, more or less land-covering distribution information is available.

The probability of the occurrence of a plant community is determined by identifying on the scale of a square kilometer for which characteristic species observations are available in the database (FLORON/NDFF). The next step is to calculate the fidelity rates of these species. Then standardization is applied by setting the highest value per plant community at 100, so that opportunity maps of different plant communities can be combined in further analyses.

Figure A2 shows the distribution of the Arrhenatheretum elatioris (Glanshaver-associatie) [146] on the left, based only on vegetation recordings as shown in Figure A2a. One could speak of a current distribution, but the picture is far from complete because vegetation recordings of the Arrhenatheretum elatioris have not been made everywhere in The Netherlands. However, a clear pattern can be seen in which the system of the large rivers is well reflected. If we then consider the opportunities map on the right in Figure A2b, we can roughly see the same pattern with the large rivers as the most important region of occurrence for the Arrhenatheretum elatioris. In comparison with the current distribution, however, it can also be seen that the Arrhenatheretum elatioris could potentially occur in many more places in The Netherlands than is currently the case. Particularly in the dunes, Zeeland and the South of Limburg, this plant community seems to have a much greater potential than the actual distribution area. 


\begin{tabular}{|c|c|c|}
\hline Plantengemeenschap & $16 \mathrm{Bb} 01$ & \multirow{30}{*}{$\begin{array}{l}\text { The numbers after the species indicate the } \\
\text { frequency in percentages with which the species can } \\
\text { be found in vegetation recordings. In superscript the } \\
\text { average covering value, also as a percentage of the } \\
\text { species. The red color indicates the degree of fidelity. } \\
\text { The degree of fidelity is a measure of the exclusivity of } \\
\text { a species within a plant community. Arrhenatherum } \\
\text { elatius (Glanshaver) and Trisetum flavescens } \\
\text { (Goudhaver) (both marked with a red color) concern } \\
\text { species that are mainly found in vegetation recordings } \\
\text { belonging to the Arrhenatheretum elatioris. The } \\
\text { degree of fidelity is also expressed as a percentage. A } \\
\text { 100\% degree of fidelity within a certain plant } \\
\text { community means that the species has not been found } \\
\text { in any other plant community. }\end{array}$} \\
\hline Glanshaver & 9520 & \\
\hline Kropaar & 905 & \\
\hline Smalle weegbree & 824 & \\
\hline Gewoon duizendblad & 773 & \\
\hline Scherpe boterbloem & $70^{3}$ & \\
\hline Rode klaver & $67^{3}$ & \\
\hline Rood zwenkgras s.l. & 6611 & \\
\hline Veldzuring & 642 & \\
\hline Knoopkruid & $62^{3}$ & \\
\hline Kweek & 614 & \\
\hline Engels raaigras & 604 & \\
\hline Goudhaver & 584 & \\
\hline Gewone berenklauw & 562 & \\
\hline Heermoes & $55^{2}$ & \\
\hline Gestreepte witbol & 543 & \\
\hline Ruw beemdgras & 514 & \\
\hline Veldbeemdgras & & \\
\hline Vijfvingerkruid & 462 & \\
\hline Peen & 452 & \\
\hline Glad walstro & 442 & \\
\hline Hondsdraf & 441 & \\
\hline Fluitenkruid & 421 & \\
\hline Gewone hoornbloem & 421 & \\
\hline Gewone paardebloemen & 411 & \\
\hline Vogelwikke & & \\
\hline Witte klaver & 381 & \\
\hline Kruipende boterbloem & 381 & \\
\hline Madeliefje & $37 \quad 1$ & \\
\hline Veldlathyrus & & \\
\hline
\end{tabular}

Figure A1. Floristic composition of the Arrhenatheretum elatioris (16Bb01) [146] (Used with permission of S. Hennekens $[180,181])$. 


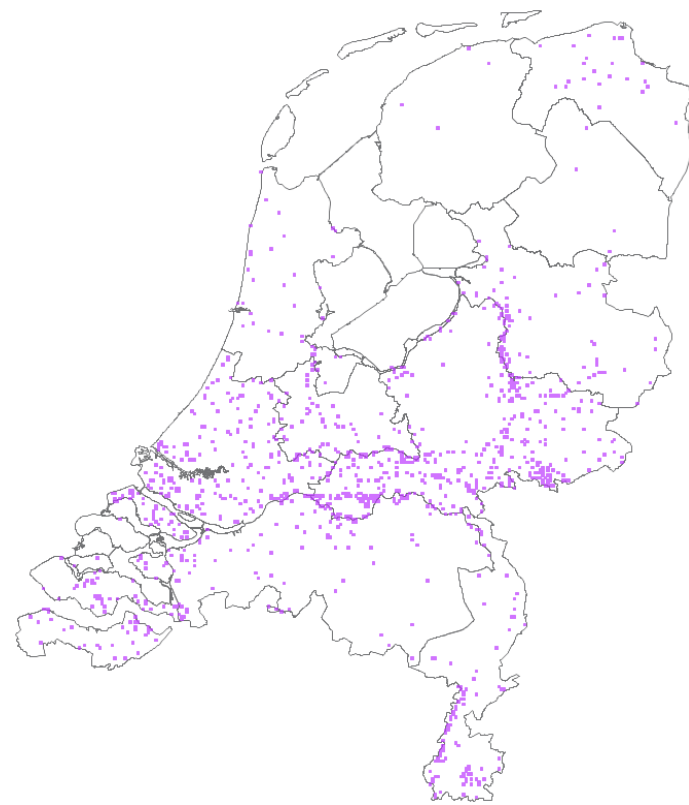

(a)

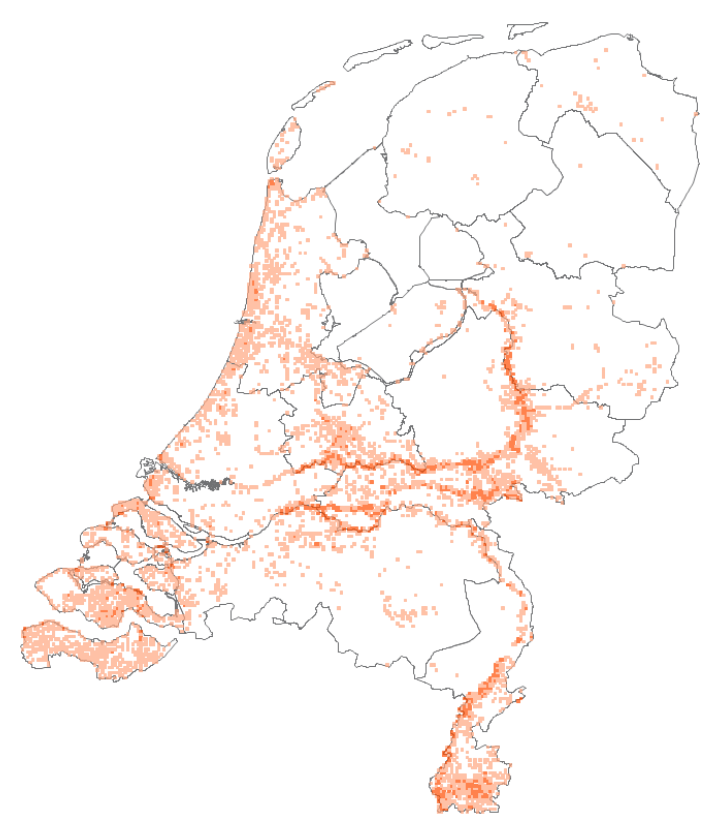

(b)

Figure A2. Maps of the Arrhenatheretum elatioris (16Bb01) [146]: (a) Actual distribution based on vegetation recordings; (b) Opportunity map based on common occurrence of characteristic species within a square kilometer. The intensity of the red color indicates the degree of occurrence. The more intense the color, the greater the chance of occurrence (used with permission of S. Hennekens $[180,181])$.

\section{Appendix A.3. Use of Ecological Opportunity Maps for Planning Considerations}

Different perspectives can be chosen for the assessment of the consequences of planning changes on biodiversity.

1. In a region it is possible to search for locations where the loss of biodiversity is expected to be limited, for example during the construction or expansion of a pig farm. By making a cross-section of stacked opportunity maps of species and plant communities, the whitest areas can be identified, i.e., the areas where the opportunities for the occurrence of species and plant communities are lowest (i.e., potentially promising planning locations). However, a selection must be made of those species and plant communities that are most sensitive in relation to the planned intervention.

2. If, as a result of a planned intervention, valuable nature is lost somewhere, compensation is mandatory. A habitat with proportional biodiversity value will therefore have to be created at another location (in the region) (or at least the ecological preconditions will have to be developed, under which the desired biodiversity will develop over time). In such a case, ecological opportunity maps can be used as search tools for identifying the potentially most suitable locations (potentially suitable compensation locations). Here again, not all opportunity maps need to be taken into consideration. If, for example, the compensation includes the restoration of a piece of nature belonging to the Ericion tetralicis (Dophei-verbond) [145], only those species and plant communities that are characteristic of it should be taken into account.

\section{References}

1. Planbureau van de Leefomgeving (PBL). Balans van de Leefomgeving 2018. Nederland Duurzaam Vernieuwen; PBL: Den Haag, The Netherlands, 2018; p. 284. Available online: https://themasites.pbl.nl/balansvandeleefomgev ing/wp-content/uploads/pbl-2018-balans-van-de-leefomgeving-2018-3160.pdf (accessed on 22 July 2019).

2. Schoukens, H. Biodiversity Banking: Voorbij de Tegenstelling Natuur Versus Economie? 2015. Available online: https://core.ac.uk/download/pdf/55803235.pdf (accessed on 22 July 2019). 
3. European Environment Agency. State of Nature in the European Union - Results from Reporting under the Nature Directives 2007-2012. EEA Technical Report; Publications Office of the European Union: Luxembourg, 2015; p. 173.

4. European Environment Agency. Annexes A-F to: State of Nature in the EU - Results from Reporting under the Nature Directives 2007-2012. EEA Technical Report; Publications Office of the European Union: Luxembourg, 2015; p. 80.

5. Bouwma, I.; Sanders, M.; Jagers op Akkerhuis, G.; Knol, O.; Verboom, J.; De Wit, B.; Wiertz, J.; Van Hinsberg, A. Biodiversiteit Bekeken: Hoe Evalueert en Verkent het PBL HET Natuurbeleid; PBL: Den Haag, The Netherlands, 2014; p. 57. Available online: https://www.pbl.nl/sites/default/files/downloads/PBL_2014_Biodiversiteit_bek eken_924_0.pdf (accessed on 19 December 2019).

6. Algemene Rekenkamer. Compensatie van Schade aan Natuurgebieden. Vervolgonderzoek Naar Bescherming van Natuurgebieden; Algemene Rekenkamer: Den Haag, The Netherlands, 2014; p. 27. Available online: https://ww w.rekenkamer.nl/publicaties/rapporten/2014/04/16/compensatie-van-schade-aan-natuurgebieden (accessed on 25 July 2018).

7. Bredenoord, H.; Van Hinsberg, A.; De Knegt, B.; Kragt, F. PBL-notitie QuickScan Hoofdlijnennotitie “Ontwikkeling en Beheer van Natuur in Nederland" Globale Toetsing van Effectiviteit en doelmatigheid; PBL: Den Haag, Wageningen, The Netherlands, 2013; p. 13. Available online: https://www.pbl.nl/sites/default/files/cms/publicaties/PBL_2 013_QuickScan-Hoofdlijnennotitie_01101.pdf (accessed on 22 July 2019).

8. Overbeek, M.; Bogaardt, M.J.; Dagevos, J. Intermediairs die Bijdragen van Burgers en Bedrijven aan Natuur en Landschap Mobiliseren; WOt-Technical Report 48; Wageningen University: Wageningen, The Netherlands, 2015; p. 50. Available online: http://library.wur.nl/WebQuery/wurpubs/reports/495459 (accessed on 22 July 2019).

9. Van Leenders, C.; Bor, A.M.; Rijksdienst voor Ondernemend Nederland. Bedrijven en Biodiversiteit. Inzichten uit de Community of Practice; Rijksdienst voor Ondernemend Nederland: The Hague, The Netherlands, 2013; pp. 1-36. Available online: www.duurzaamdoor.nl/bedrijven-en-biodiversiteit (accessed on 22 July 2019).

10. Farjon, H.; Arnouts, R. Leren van Het Energieke Platteland. Lokale en Regionale Coalities Voor Duurzame Plattelandsontwikkeling; PBL: Den Haag, The Netherlands, 2013; p. 86. Available online: https://www.pbl. nl/sites/default/files/downloads/PBL_2013_Hoofdrapport_Het_energieke_platteland_769.pdf (accessed on 25 July 2018).

11. Van den Berg, A. Beleving en Participatie Natuur, Landschap en Groen in Limburg-Resultaten Enquêtes Onder Burgers en Bedrijven; Province of Limburg: Maastricht, The Netherlands, 2015; p. 81.

12. Van den Berg, A. Beleving van Natuur en Landschap in Brabant. Draagvlak- en Belevingsonderzoek Voor het Provinciaal Natuur- en Landschapsbeleid; Province of North Brabant: Hertogenbosch, The Netherlands, 2012; p. 53. Available online: https://www.brabant.nl/-/media/B2396D605C3E4DA6BB130FFCA438EFCF.pdf (accessed on 13 June 2012).

13. TEEB - The Economics of Ecosystems and Biodiversity. TEEB-The Economics of Ecosystems and Biodiversity for Local and Regional Policy Makers; TEEB: Mriehel, Malta, 2010; Available online: http://www.teebweb.org/media/2010/09/TEEB_D2_Local_Policy-Makers_Report-Eng.pdf\%5Cnhttp:

//www.teebweb.org/wp-content/uploads/Study/and/Reports/Reports/Local/and/Regional/Policy/Makers/ D2/Report/Translations/layTEEB_D2_Druckvar_end_ES.pdf (accessed on 23 July 2019).

14. Bull, J.W.; Suttle, K.B.; Gordon, A.; Singh, N.J.; Milner-Gulland, E.J. Biodiversity offsets in theory and practice. Oryx 2013, 47, 369-380. [CrossRef]

15. Gorissen, M.; Van der Heide, C.; Schaminée, J.; Ruijs, A. Van Dominee tot Koopman? Habitatbanking in Nederland; Wageningen Economic Research: Wageningen, The Netherlands, 2017; p. 120. Available online: https://ibrary.wur.nl/WebQuery/wurpubs/fulltext/406102 (accessed on 12 November 2018).

16. Ministery of Economic Affairs. The Natural Way forward. Government Vision on Nature; Ministery of Economic Affairs: The Hague, The Netherlands, 2014; p. 55. Available online: https://www.rijksoverheid.nl/documente n/beleidsnota-s/2014/04/11/natuurlijk-verder (accessed on 19 July 2019).

17. Swanenvleugel, B.; Play-Time, Bunde, The Netherlands. Vermaatschappelijking in het Fysieke Domein. Personal communication, 2012.

18. De Bie, S.; Warmenhoven, H. Vooronderzoek Habitatbanking: Voorstellen voor de systematiek, organisatie en uitvoering van habitatbanking in Nederland. In Een Onderzoek in Opdracht van het Platform Biodiversiteit, Ecosystemen en Economie (PBEE); De Gemeynt: Klarenbeek, The Netherlands, 2012; p. 105. Available online: http://www.platformbee.nl/assets/Pb2012-001_Voorstudie_Habitatbanking.pdf (accessed on 25 July 2019). 
19. Eftec; IEEP. The use of market-based instruments for biodiversity protection-The case of habitat banking. In Technical Report for European Commission DG Environment; Eftec: London, UK, 2010; p. 269. Available online: http://ec.europa.eu/environment/enveco/pdf/eftec_habitat_technical_report.pdf (accessed on 12 July 2019).

20. Eftec; IEEP. The use of market-based instruments for biodiversity protection-The case of habitat banking. In Summary Report for European Commission DG Environment; Eftec: London, UK, 2010; p. 43. Available online: https://ieep.eu/uploads/articles/attachments/ca7fa04d-df03-46a5-887e-5ea111c3ae77/eftec_habitat_ banking_summary_report.pdf?v=63664509726 (accessed on 23 July 2019).

21. Bekessy, S.A.; White, M.; Gordon, A.; Moilanen, A.; Mccarthy, M.A.; Wintle, B.A. Transparent planning for biodiversity and development in the urban fringe. Landsc. Urban Plan. 2012, 108, 140-149. [CrossRef]

22. Business and Biodiversity Offsets Programme (BBOP). Biodiversity Offset Design Handbook; BBOP: Washington DC, USA, 2009; p. 105. Available online: https://www.forest-trends.org/wp-content/uploads/imported/biod iversity-offset-design-handbook-pdf.pdf (accessed on 23 July 2019).

23. Conway, M.; Rayment, M.; White, A.; Berman, S. Exploring Potential Demand for and Supply of Habitat Banking in the EU and Appropriate Design Elements for a Habitat Banking Scheme; Final Report submitted to DG Environment; ICF GHK: London, UK, 2013; p. 158. Available online: http://ec.europa.eu/environment/envec o/taxation/pdf/Habitat_banking_Report.pdf (accessed on 21 July 2019).

24. Vaissière, A.C.; Levrel, H. Biodiversity offset markets: What are they really? An empirical approach to wetland mitigation banking. Ecol. Econ. 2015, 114, 81-88. [CrossRef]

25. De Koe, M.; Provincie Flevoland, Lelystad, The Netherlands; Verbeek, I.C.; Provincie Flevoland, Lelystad, The Netherlands. Natuurcompensatiebank in Flevoland Verkenning Naar Mogelijkheden en Kansen. Unpublished. Personal communication, 2010.

26. Blom, M.; Bergsma, G.; Korteland, M. Economic Instruments for bIODIVERSITY. Setting up a Biodiversity Trading System in Europe; CE Delft: Delft, The Netherlands, 2008; p. 77. Available online: https://www.ce.nl/publicat ies/download/651 (accessed on 9 September 2019).

27. Creswell, J.; Poth, C. Qualiltative Inquiry \& Research Design. Choosing Among Five Approches; SAGE Publications Inc.: London, UK, 2018; p. 459.

28. Sijtsma, F.; Van Hinsbergen, A.; Kruitwagen, S.; Dietz, F. Natuureffecten in de MKBA's van Projecten Voor Integrale Gebiedsontwikkeling; PBL: Den Haag, Bilthoven, The Netherlands, 2009; p. 37. Available online: https://www.pbl.nl/sites/default/files/downloads/500141004.pdf (accessed on 18 November 2018).

29. De Blaeij, A.; Verburg, R. Voor-en Nadelen van het Gebruik van Natuurpunten bij het Bepalen en Monetariseren van Natuureffecten; LEI: Den Haag, The Netherlands, 2011; p. 35. Available online: http://edepot.wur.nl/189816 (accessed on 2 September 2019).

30. Van Gaalen, F.; Van Hinsberg, A.; Franken, R.; Vonk, M.; Van Puijenbroek, P.; Wortelboer, R. Natuurpunten: Kwantificering van Effecten op Natuurlijke Ecosystemen en Biodiversiteit in Het Deltaprogramma. Achtergrondstudie; PBL: Den Haag, The Netherlands, 2014; p. 94. Available online: http://www.pbl.nl/sites/default/files/cms/pub licaties/PBL_2014_Natuurpunten_Achtergrondstudie_1263.pdf (accessed on 14 March 2019).

31. Groenfonds, N.; Nationaal Groenfonds, Hoevelaken, The Netherlands; Van Groenendael, J.; Nationaal Groenfonds, Hoevelaken, The Netherlands. Instrumenten Natuurcompensatie. Natuurpunten en Natuurbank. Kennisdocument. Unpublished. Personal communication, 2014.

32. Groenfonds, N.; Nationaal Groenfonds, Hoevelaken, The Netherlands; Van Groenendael, J.; Nationaal Groenfonds, Hoevelaken, The Netherlands. Instrumenten Natuurcompensatie. Natuurpunten en Natuurbank. Kennisdocument. Unpublished. Personal communication, 2013.

33. Jaspers, C.; Mouissie, M.; Wessels, S.; Barke, J.; Kolen, M.; Bucholc, A. Natuurpuntensysteem voor een Uniforme Waardering van Natuurkwaliteit; Sweco: Houten, The Netherlands, 2016; Available online: http://docplayer.nl /25162430-Natuurpuntensysteem-voor-een-uniforme-waardering-van-natuurkwaliteit.html (accessed on 14 November 2018).

34. Kalisvaart, M.; Van Groenendael, J. Natuurcompensatie - voor wat hoort wat. In Natuur in de Uitverkoop? Beschouwingen over Ecologie en Economie; Schaminée, J., Janssen, J., Van der Heide, M., Eds.; KNNV Uitgeverij: Zeist, The Netherlands, 2013; Vegetatiekundige Monografieën 5; pp. 59-77.

35. Holstege, S. Natuurcompensatie. Een Onderzoek Naar de Effectiviteit van het Nederlandse Compensatieproces. Master's Thesis, Utrecht University, Utrecht, The Netherlands, 23 March 2012; p. 101. Available online: https://dspace.library.uu.nl/handle/1874/242234 (accessed on 24 July 2019). 
36. Volkers, B. Eindrapport Stuurgroep Natuurcompensatie; Stuurgroep Natuurcompensatie: Den Haag, The Netherlands, 2013; p. 35. Available online: http://florafaunawet.stowa.nl/Upload/Flora-enfaunawet/eind rapport-stuurgroep-natuurcompensatie.pdf (accessed on 25 July 2019).

37. Gordon, A.; Bull, J.W.; Wilcox, C.; Maron, M. Perverse incentives risk undermining biodiversity offset policies. J. Appl. Ecol. 2015, 52, 532-537. [CrossRef]

38. Leroy, P.; Gersie, J. Een historisch tegendraadse ambitie: De vermaatschappelijking van het natuurbeleid in Nederland. In Medeverantwoordelijkheid voor Natuur; Overbeek, G., Lijmbach, S., Eds.; Wageningen Academic Publishers: Wageningen, The Netherlands, 2004; pp. 23-44. Available online: http://www.wageningenacad emic.com/books/natuur_inleiding.pdf (accessed on 24 July 2018).

39. Dammers, E.; Ludwig, K.; Van Puijenbroek, P.; Tisma, A.; Van Tol, S.; Vonk, M.; Bouwma, I.; Farjon, H.; Gerritsen, A.; Pedrolli, B.; et al. Perspectives on the Future of Nature in Europe: Storylines and Visualisations. Background Report; PBL: The Hague, The Netherlands, 2017; p. 146. Available online: http://themasites.pbl.nl/ natureoutlook/2016/ (accessed on 25 July 2019).

40. Zuidelijke Rekenkamer. Kwaliteit Natuurcompensatie Provincie Limburg (vervolgonderzoek). Deel I Bestuurlijk Rapport; Zuidelijke Rekenkamer: Eindhoven, The Netherlands, 2013; p. 27. Available online: https://zuidelij kerekenkamer.nl/wp-content/uploads/2014/07/000454_br-natuurcompensatie-limburg-301013.pdf (accessed on 22 July 2019).

41. Zuidelijke Rekenkamer. Kwaliteit Natuurcompensatie Provincie Limburg. Deel II Rapport van Bevindingen; Zuidelijke Rekenkamer: Eindhoven, The Netherlands, 2009; p. 71. Available online: https://www.zuidelijke rekenkamer.nl/2013-kwaliteit-natuurcompensatie-provincie-limburg/ (accessed on 22 July 2019).

42. Zuidelijke Rekenkamer. Kwaliteit Natuurcompensatie Provincie Noord-Brabant (Vervolgonderzoek). Deel I Bestuurlijk Rapport; Zuidelijke Rekenkamer: Eindhoven, The Netherlands, 2014; p. 32. Available online: https://www.zuidelijkerekenkamer.nl/2014-kwaliteit-natuurcompensatie-provincie-noord-brabant -vervolgonderzoek/ (accessed on 22 July 2019).

43. Zuidelijke Rekenkamer. Kwaliteit Natuurcompensatie Provincie Noord-Brabant (Vervolgonderzoek). Deel II Rapport van Bevindingen; Zuidelijke Rekenkamer: Eindhoven, The Netherlands, 2014; p. 105. Available online: https://www.zuidelijkerekenkamer.nl/2014-kwaliteit-natuurcompensatie-provincie-noord-brabant -vervolgonderzoek/ (accessed on 22 July 2019).

44. Carpenter, S.R.; Mooney, H.A.; Agard, J.; Capistrano, D.; DeFries, R.S.; Diaz, S.; Dietz, T.; Duraiappah, A.K.; Oteng-Yeboah, A.; Pereira, H.M.; et al. Science for managing ecosystem services: Beyond the Millennium Ecosystem Assessment. Proc. Natl. Acad. Sci. USA 2009, 106, 1305-1312. [CrossRef]

45. Chan, K.M.; Balvanera, P.; Benessaiah, K.; Chapman, M.; Díaz, S.; Gómez-Baggethun, E.; Gould, R.; Hannahs, N.; Jax, K.; Klain, S.; et al. Why protect nature? Rethinking values and the environment. Proc. Natl. Acad. Sci. USA 2016, 113, 1462-1465. [CrossRef]

46. Van den Born, R.J.; Arts, B.; Admiraal, J.; Beringer, A.; Knights, P.; Molinario, E.; Polajnar Horvat, K.; Porras-Gomez, C.; Smrekar, A.; Soethe, N.; et al. The missing pillar: Eudemonic values in the justification of nature conservation. J. Environ. Plan. Manag. 2018, 61, 841-856. [CrossRef]

47. Drenthen, M. Natuur in Mensenland. Essays over ons Nieuwe Cultuurlandschap; KNNV Uitgeverij: Zeist, The Netherlands, 2018; p. 255.

48. Millenium Ecosystem Assessment (MEA). Ecosystems and Human Well-Being: A Framework for Assessment; MEA: Washington DC, USA, 2003; p. 266. Available online: http://pdf.wri.org/ecosystems_human_wellbeing.pdf (accessed on 14 December 2018).

49. Millennium Ecosystem Assessment (MEA). Ecosystems and Human Well-Being: Biodiversity Synthesis; MEA: Washington DC, USA, 2005; p. 285. Available online: https://www.millenniumassessment.org/documents/d ocument.354.aspx.pdf (accessed on 6 September 2018).

50. Bateman, I.J.; Mace, G.M.; Fezzi, C.; Atkinson, G.; Turner, K. Economic analysis for ecosystem service assessments. Environ. Resour. Econ. 2011, 48, 177-218.

51. Elkington, J. Towards the Sustainable Corporation: Win-Win-Win Business Strategies for Sustainable Development. Calif. Manag. Rev. 1994, 36, 90-100. [CrossRef]

52. Veeneklaas, F.; Salverda, I.; Van Dam, R.; During, R. Empirisch onderzoek naar de relatie Mens_-Natuur/Groen. Een State of the Art; Alterra, Wageningen UR: Wageningen, The Netherlands, 2011; p. 112. Available online: https://edepot.wur.nl/176836 (accessed on 22 July 2019). 
53. Turner, R.K.; Paavola, J.; Cooper, P.; Farber, S.; Jessamy, V.; Georgiou, S. Valuing nature: Lessons learned and future research directions. Ecol. Econ. 2003, 46, 493-510. [CrossRef]

54. Winthrop, R.H. The strange case of cultural services: Limits of the ecosystem services paradigm. Ecol. Econ. 2014, 108, 208-214. [CrossRef]

55. Van Dam, R.; Salverda, I.; During, R.; Duineveld, M. Burgers en hun Landschap: Burgerparticipatie en Maatschappelijk Initiatief; Alterra: Wageningen, The Netherlands, 2014; p. 253. Available online: https://www. wur.nl/nl/Publicatie-details.htm?publicationId=publication-way-343737333139 (accessed on 17 August 2019).

56. Nowak, M.A.; Sigmund, K. Evolution of indirect reciprocity. Nature 2005, 437, 1291-1298. [CrossRef]

57. Van der Steen, M.; Van Twist, M.; Chin-A-Fat, N.; Kwakkelstein, T. Pop-up Publieke Waarde-Overheidssturing in een Context van Maatschappelijke Zelforganisatie; Nederlandse School voor Openbaar Bestuur (NSOB): Den Haag, The Netherlands, 2013; p. 60. Available online: https://www.nsob.nl/wp-content/uploads/2015/08/Pop-up-publieke-waarde.-Overheidssturing-in -de-context-van-maatschappelijke-zelforganisatie.-NSOB.-2013.pdf (accessed on 20 August 2018).

58. Bredenoord, H.; Van Broekhoven, S.; Dirkx, J.; Van Doren, D.; Folkert, R.; Kunseler, E.; Verwest, F.; Vugteveen, P.; Westerink, J. Naar een Kennisagenda voor Vermaatschappelijking van Natuur. Achtergrondstudie; PBL: Den Haag, The Netherlands, 2018; p. 57. Available online: https:/www.pbl.nl/sites/default/files/cms/p ublicaties/3339_KennisagendaVermaatschappelijkingvannatuurwebsiteversie.pdf (accessed on 19 July 2019).

59. Wensink, R. Habitat Banking. Instrument or Alibi for Nature Conservation and Its Societalization? Master's Thesis, Radboud University, Nijmegen, The Netherlands, January 2019; p. 102. Available online: https:/theses.ubn.ru.nl/bitstream/handle/123456789/7213/Wensink\%2C_Ramon_1.pdf?sequence=1 (accessed on 19 July 2019).

60. Raad voor het openbaar bestuur (Rob). Loslaten in Vertrouwen. Naar een Nieuwe Verhouding Tussen Overheid, Markt én Samenleving; Rob: Den Haag, The Netherlands, 2012; p. 84. Available online: https://kennisopenba arbestuur.nl/media/63034/loslaten-in-vertrouwen.pdf (accessed on 26 July 2019).

61. Hajer, M. De Energieke Samenleving. Op Zoek Naar een Sturingsfilosofie voor een Schone Economie; PBL: Den Haag, The Netherlands, 2011; p. 78. Available online: https:/www.pbl.nl/sites/default/files/downloads/Signa lenrapport_web.pdf (accessed on 10 January 2019).

62. Bergsma, G.; Odegard, I.; De Bie, S.; Head, M.; Croezen, H. Benchmark Biodiversiteit. De Impact op Biodiversiteit van Nederlandse Sectoren en Bedrijven; CE Delft: Delft, The Netherlands, 2014; p. 152. Available online: https://www.ce.nl/publicaties/download/1650 (accessed on 28 July 2019).

63. Buijs, A.; Elands, B.; Van Koppen, C. Vijfentwintig jaar Burgerbetrokkenheid in het Natuurbeleid. Analyse van Beleidsdiscoursen en Publiek Draagvlak; WOt-Technical Report 103; Wageningen University \& Research: Wageningen, The Netherlands, 2017; p. 86. Available online: https://edepot.wur.nl/428786 (accessed on 22 July 2019).

64. Buijs, A.; Langers, F.; Mattijssen, T.; Salverda, I. Draagvlak in de Energieke Samenleving: Van Acceptatie naar Betrokkenheid en Legitimatie; Alterra, Wageningen University: Wageningen, The Netherlands, 2012; p. 86. Available online: https://edepot.wur.nl/238760 (accessed on 25 July 2018).

65. Kistenkas, F.; Nieuwenhuizen, W.; Kamphorst, D.; Broekmeyer, M. Natuur en Landschap in de Omgevingswet; WOt-Technical Report 133; Wageningen University \& Research: Wageningen, The Netherlands, 2018; p. 50. Available online: https://edepot.wur.nl/465835 (accessed on 13 October 2018).

66. Bergmans, F. Integrating People, Planet and Profit. In Management Models for Corporate Social Responsibility; Jonker, J., De Witte, M., Bergmans, F., Eds.; Springer: Heidelberg, Germany, 2006; pp. 117-125. Available online: https://link.springer.com/chapter/10.1007\%2F3-540-33247-2_14 (accessed on 22 August 2018).

67. Elkington, J. Partnerships from cannibals with forks: The triple bottom line of 21st-century business. Environ. Qual. Manag. 1998, 8, 37-51. [CrossRef]

68. Elkington, J. Enter the triple bottom line. In The Triple Bottom Line: Does it All Add Up; Richardson, J., Ed.; Earthscan: London, UK, 2004; pp. 1-16. Available online: https://www.johnelkington.com/archive/TBL-elki ngton-chapter.pdf (accessed on 26 July 2018).

69. Fisk, P. People, Planet, Profit: How to Embrace Sustainability for Innovation and Business Growth; Kogan Page: London, UK, 2010; p. 240.

70. Campagna, C.; Guevara, D.; Le Boeuf, B. Sustainable development as deus ex machina. Biol. Conserv. 2017, 209, 54-61. [CrossRef] 
71. United Nations General Assembly. Transforming our world: The 2030 agenda for sustainable development. In Proceedings of the 4th Plenary Meeting of the General Assembly, New York, NY, USA, 25 September 2015; United Nations General Assembly: New York, NY, USA, 2015; p. 34. Available online: https: //sustainabledevelopment.un.org/content/documents/7891Transforming\%20Our\%20World.pdf (accessed on 20 July 2018).

72. Wiertz, J. Ecologische Overwegingen bij Verdeling van Middelen Tussen en Binnen Provincies voor een Herijkte EHS; PBL: Den Haag, The Netherlands, 2018; p. 26. Available online: https://www.pbl.nl/sites/default/files/cms/publicaties/PBL_2012_Ecologische_overwegingen_bij_v erdeling_van_middelen_tussen_en_binnen_provincies_voor_een_Herijkte_EHS_500070013.pdf (accessed on 18 August 2019).

73. Nationaal Groenfonds. Jaarverslag 2013; Nationaal Groenfonds: Hoevelaken, The Netherlands, $2014 ;$ p. 80. Available online: https://www.nationaalgroenfonds.nl/storage/app/media/uploaded-files/Nationaal_Groenfo nds_Jaarverslag_2013.pdf (accessed on 23 August 2019).

74. Schaminée, J.; Janssen, J.; Van der Heide, M. Natuur in de Uitverkoop? Beschouwingen over Ecologie en Economie; KNNV: Zeist, The Netherlands, 2013; Vegetatiekundige Monografieën 5; p. 161.

75. Taskforce Biodiversiteit en Natuurlijke Hulpbronnen. Groene groei: Investeren in Biodiversiteit en Natuurlijke Hulpbronnen; Schefferdrukkerij: Dordrecht, The Netherlands, 2011; p. 93. Available online: https://www.rijksoverheid.nl/documenten/rapporten/2012/03/06/rapport-groene-groei-investeren-i n-biodiversiteit-en-natuurlijke-hulpbronnen (accessed on 4 May 2019).

76. Platform for Biodiversity Ecosystems and Economy (Platform BEE). Available online: https://naturalcapital.fut ureproof.community/cirkels/platform-bee-stimuleren-van-natuurlijk-kapitaal-in-het-bedrijfsleven (accessed on 23 August 2019).

77. IUCN NL. Available online: https://www.iucn.nl/themas/groene-economie; https://www.iucn.nl/partners (accessed on 23 August 2019).

78. Naturalcapitals.community. Available online: https://naturalcapital.futureproof.community; https: //natrualcapital.futureproof.community/ondernemersvraag?q=habitat\%20banking\#/filter/ (accessed on 23 August 2019).

79. Van Egmond, P.; Ruijs, A. Natuurlijk Kapitaal: Naar Waarde Geschat; PBL: Den Haag, The Netherlands, 2016; p. 162. Available online: https://hemasites.pbl.nl/natuurlijk-kapitaal-nederland/wp-content/uploads/2014/ PBL_2016_Natuurlijk-kapitaal_1455.pdf (accessed on 20 November 2018).

80. Natuurlijk Kapitaal Nederland | Natuur \& Economie Verbinden. Available online: https://themasites.pbl.n 1/natuurlijk-kapitaal-nederland/; https://www.pbl.nl/publicaties/natuurlijk-kapitaal-naar-waarde-geschat (accessed on 23 August 2019).

81. Ostrom, E. Governing the Commons. The Evolution of Institutions for Collective Action, 29th ed.; Cambridge University Press: Cambridge, UK, 1990; p. 280.

82. Ostrom, E. A general framework for analyzing sustainability of social-ecological systems. Science 2009, 325, 419-422. [CrossRef]

83. Business and Biodiversity Offsets Programme (BBOP). Guidance Notes to the Standard on Biodiversity Offsets; BBOP: Washington DC, USA, 2012; p. 121. Available online: http://bbop.forest-trends.org/guidelines/index. php (accessed on 23 July 2019).

84. Bor, J.; Petersma, E.; Kingma, J. De Verbeelding van het Denken. Geïllustreerde Geschiedenis van de Westerse en Oosterse Filosofie; Tweede druk; Uitgeverij Contact: Amsterdam, The Netherlands; Antwerpen, Belgium, 1996; p. 400.

85. Capra, F.; Luisi, P. The Systems View of Life. A Unifying Vision, 4th ed.; Cambridge University Press: Cambridge, UK, 2014; p. 498.

86. Buijs, A. Public Natures. Social Representations of Nature and Local Practices. Ph.D. Thesis, Wageningen University, Wageningen, The Netherlands, 11 September 2009; p. 296. Available online: http://library.wur.nl /WebQuery/wurpubs/382322 (accessed on 24 July 2018).

87. Apostolopoulou, E.; Adams, W.M. Biodiversity offsetting and conservation: Reframing nature to save it. Oryx 2017, 51, 23-31. [CrossRef]

88. Spash, C.L. Bulldozing biodiversity/: The economics of offsets and trading-in Nature. Biol. Conserv. 2015, 192, 541-551. [CrossRef] 
89. Devictor, V. When conservation challenges biodiversity offsetting. Biol. Conserv. 2015, 192, $483-484$. [CrossRef]

90. Koh, N.S.; Hahn, T.; Boonstra, W.J. How much of a market is involved in a biodiversity offset? A typology of biodiversity offset policies. J. Environ. Manag. 2019, 232, 679-691. [CrossRef]

91. Gómez-Baggethun, E.; de Groot, R.; Lomas, P.L.; Montes, C. The history of ecosystem services in economic theory and practice: From early notions to markets and payment schemes. Ecol. Econ. 2010, 69, 1209-1218. [CrossRef]

92. Vatn, A. The environment as a Commodity. Environ. Values 2000, 9, 493-509. [CrossRef]

93. Vatn, A. Institutions and the Environment; Edward Elgar Publishing Limited: Cheltenham, UK, $2005 ;$ p. 481. Available online: https://books.google.nl/books/about/Institutions_And_The_Environment.html?id=1mYnA QAAIAAJ\&redir_esc=y (accessed on 23 September 2019).

94. McGrath, M. 'Licence to trash' offsetting scheme set back until autumn. 2013. Available online: https: //www.bbc.com/news/science-environment-23502362 (accessed on 20 September 2019).

95. Apostolopoulou, E.; Adams, W.M. Neoliberal capitalism and conservation in the post-crisis era: The dialectics of "Green" and "Un-green" Grabbing in Greece and the UK. Antipode 2015, 47, 15-35. [CrossRef]

96. Hooper, D.U.; Adair, E.C.; Cardinale, B.J.; Byrnes, J.E.; Hungate, B.A.; Matulich, K.L.; Gonzalez, A.; Duffy, J.E.; Gamfeldt, L.; O'Connor, M.I. A global synthesis reveals biodiversity loss as a major driver of ecosystem change. Nature 2012, 486, 105-109. [CrossRef]

97. Dirkx, J.; De Knegt, B. Natuurlijk Kapitaal als Nieuw Beleidsconcept. Balans van de Leefomgeving 2014. Deel 7; PBL: Den Haag, The Netherlands, 2014; p. 26. Available online: https://library.wur.nl/WebQuery/wurpubs/ 456932 (accessed on 5 September 2019).

98. Ring, I.; Hansjürgens, B.; Elmqvist, T.; Wittmer, H.; Sukhdev, P. Challenges in framing the economics of ecosystems and biodiversity: The TEEB initiative. Curr. Opin. Environ. Sustain. 2010, 2, 15-26. [CrossRef]

99. Díaz, S.; Demissew, S.; Carabias, J.; Joly, C.; Lonsdale, M.; Ash, N.; Larigauderie, A.; Adhikari, J.R.; Arico, S.; Báldi, A.; et al. The IPBES Conceptual Framework-Connecting nature and people. Curr. Opin. Environ. Sustain. 2015, 14, 1-16. [CrossRef]

100. Pascual, U.; Balvanera, P.; Díaz, S.; Pataki, G.; Roth, E.; Stenseke, M.; Watson, R.T.; Başak Dessane, E.; Islar, M.; Kelemen, E.; et al. Valuing nature's contributions to people: The IPBES approach. Curr. Opin. Environ. Sustain. 2017, 26-27, 7-16. [CrossRef]

101. Pascual, U.; Muradian, R.; Brander, L.; Gómez-Baggethun, E.; Martín-López, B.; Madhu, V.; Amsworth, P.; Christie, M.; Cornelissen, H.; Eppink, F.; et al. Chapter 5 The economics of valuing ecosystem services and biodiversity. In The Economics of Ecosystems and Biodiversity. The Ecological and Economic Foundations; TEEB Document; Routledge: London, UK, 2010; pp. 183-255. Available online: https://www.researchgate.net/profile/Unai_Pascual/publication/303444184_The_Economics_of_Valuing_Ec osystem_Services_and_Biodiversity/links/5746b08208aea45ee8561db8/The-Economics-of-Valuing-Ecosys tem-Services-and-Biodiversity.pdf (accessed on 24 October 2018).

102. Geneletti, D. Handbook on Biodiversity and Ecosystem Services in Impact Assessment; Edward Elgar Publishing: Cheltenham/Northampton, UK, 2016; p. 511. Available online: https://books.google.nl/books?hl=nl\&lr=\&id $=\mathrm{q} 3 \mathrm{dmDAAAQBAJ} \& \mathrm{oi}=\mathrm{fnd} \& \mathrm{pg}=\mathrm{PR} 1 \& \mathrm{dq}=$ Handbook + on + Biodiversity + and + Ecosystem + Services $+\mathrm{in}+$ Impact+Assessment\&ots=dt7XJfpoKV\&sig=p9MnLrouktFe_WXWGAzR17EISd0\#v=onepage\&q=Handb ook/on/Biodiversity/and/Ecosystem/Services/in/Impact/Assessment\&f=false (accessed on 5 September 2019).

103. Moreno-mateos, D.; Maris, V.; Béchet, A.; Curran, M. The true loss caused by biodiversity offsets. Biol. Conserv. 2015, 192, 552-559. [CrossRef]

104. Remme, R.P.; Schröter, M.; Hein, L. Developing spatial biophysical accounting for multiple ecosystem services. Ecosyst. Serv. 2014, 10, 6-18. [CrossRef]

105. Remme, R.P.; Schröter, M. Effects of budget constraints on conservation network design for biodiversity and ecosystem services. Ecol. Complex. 2016, 26, 45-56. [CrossRef]

106. Remme, R.P. Accounting for Ecoystem Services and Biodiversity in Limburg Province, The Netherlands. Ph.D. Thesis, Wageningen University, Wageningen, The Netherlands, 13 January 2016; p. 220.

107. Adams, R.; Jeanrenaud, S.; Bessant, J.; Denyer, D.; Overy, P. Sustainability-oriented Innovation: A Systematic Review. Int. J. Manag. Rev. 2016, 18, 180-205. [CrossRef]

108. Raworth, K. A Doughnut for the Anthropocene: Humanity's compass in the 21st century. Lancet Planet. Health 2017, 1, 48-49. [CrossRef] 
109. Rockström, J.; Steffen, W.; Noone, K.; Persson, Å.; Chapin, F.S.; Lambin, E.F.; Lenton, T.M.; Scheffer, M.; Folke, C.; Schellnhuber, H.J.; et al. A safe operating space for humanity. Nature 2009, 461, 472-475. [CrossRef]

110. Buijs, A.; Hovardas, T.; Figari, H.; Castro, P.; Devine-Wright, P.; Fischer, A.; Mouro, C.; Selge, S. Understanding People's Ideas on Natural Resource Management: Research on Social Representations of Nature. Soc. Nat. Resour. 2012, 25, 1167-1181.

111. Díaz, S.; Pascual, U.; Stenseke, M.; Martín-López, B.; Watson, R.T.; Molnár, Z.; Hill, R.; Chan, K.M.; Baste, I.A.; Brauman, K.A.; et al. Assessing nature's contributions to people. Recognizing culture, and diverse sources of knowledge, can improve assessments. Science 2018, 359, 270-272.

112. Piccolo, J.J. Intrinsic values in nature: Objective good or simply half of an unhelpful dichotomy? J. Nat. Conserv. 2017, 37, 8-11. [CrossRef]

113. Arias-Arévalo, P.; Martín-López, B.; Gómez-Baggethun, E. Exploring intrinsic, instrumental, and relational values for sustainable management of social-ecological systems. Ecol. Soc. 2017, 22, 1-15. [CrossRef]

114. Foucault, M. The Archaeology of Knowledge and the Discourse on Language; Pantheon Books: New York, NY, USA, 1972; p. 252. Available online: https://archive.org/details/TheArchaeologyOfKnowledge/page/n1 (accessed on 19 July 2019).

115. Pepper, D. Modern Environmentalism. An Introduction; Routledge: London, UK; New York, NY, USA, 1996; p. 376. Available online: https://books.google.nl/books?hl=nl\&lr=\&id=AF7qoVccgLoC\&oi=fnd\&pg=PA1\& $\mathrm{dq}=$ Modern+environmentalism.+An+introduction.+Pepper\&ots=KI2ehRj5W6\&sig=e8Et5PzEX5ttU_zDx XB_JH92RwI\#v=onepage\&q=Modern\%20environmentalism.\%20An\%20introduction.\%20Pepper\&f=false (accessed on 4 October 2018).

116. Admiraal, J.F.; Van Den Born, R.J.; Beringer, A.; Bonaiuto, F.; Cicero, L.; Hiedanpää, J.; Knights, P.; Knippenberg, L.W.; Molinario, E.; Musters, C.J.; et al. Motivations for committed nature conservation action in Europe. Environ. Conserv. 2017, 44, 148-157. [CrossRef]

117. Ganzevoort, W.; Van Den Born, R.J.; Halffman, W.; Turnhout, S. Sharing biodiversity data: Citizen scientists' concerns and motivations. Biodivers. Conserv. 2017, 26, 2821-2837. [CrossRef]

118. Knippenberg, L. (Ed.) Motivation for Biodiversity Action: Vocabulary, Theories and Framework; BIOMOT: Nijmegen, The Netherlands, 2013; pp. 1-142.

119. Ives, C.D.; Kendal, D. The role of social values in the management of ecological systems. J. Environ. Manag. 2014, 144, 67-72. [CrossRef]

120. Munda, G. Social multi-criteria evaluation: Methodological foundations and operational consequences. Eur. J. Oper. Res. 2004, 158, 662-677. [CrossRef]

121. Escobar, A. Construction Nature. Elements for a post-structuralist political ecology. Futures 1996, 28 , 325-343. [CrossRef]

122. Bugter, R.; Vader, J.; Van den Hoven, M. Investeren in Natuur: Naar Pilots voor een Bredere Vorm van Habitatbanking; Wageningen UR: Wageningen, The Netherlands, 2017; p. 60. Available online: http: //library.wur.nl/WebQuery/wurpubs/fulltext/413468 (accessed on 18 April 2019).

123. Wiltink, H.; Warmenhoven, H.; De Bie, S. Habitatbanking Gelderland, Rapportage Pilots. Samenvattende Rapportage; Gemeynt: Klarenbeek, The Netherlands, 2017; p. 20. Available online: https://www.gemeynt.nl/n 1/download/eindrapport-habitatbanking-gelderland/ (accessed on 13 June 2019).

124. Jaspers, C.J.; Provincie Flevoland, Lelystad, The Netherlands; Mouissie, A.M.; Provincie Flevoland, Lelystad, The Netherlands. Rekeneenheid Natuurboekhouding Markermeer. Onderzoek naar de Geschiktheid van Rekeneenheden voor een Toekomstig Natuurboekhoudsysteem ten Behoeve van TBES. Unpublished. Personal communication, 2014.

125. Argyris, C.; Schön, D.A. Organizational Learning: A Theory of Action Perspective. Reis 1997, 77, 345-348. [CrossRef]

126. Swieringa, J.; Wierdsma, A. Op Weg Naar een Lerende Organisatie. Over het Leren en Opleiden van Organisaties; Wolters-Noordhoff Uitgevers: Groningen, The Netherlands, 1990; p. 170.

127. Senge, P. De Vijfde Discipline. De Kunst E Praktijk van de Lerende Organisatie; Scriptum Books: Schiedam, The Netherlands, 1992; p. 399.

128. Argyris, C. On Organizational Learning, 2nd ed.; Wiley: Antwerpen, Belgium, 1999; p. 480.

129. Greenwood, D. Organizational Learning II: Theory, Method, and Practice. ILR Rev. 1997, 50, 701. [CrossRef] 
130. Zuidelijke Rekenkamer. De Provincie Limburg als Lerende Organisatie; Zuidelijke Rekenkamer: Eindhoven, The Netherlands, 2014; p. 54. Available online: https://www.zuidelijkerekenkamer.nl/?s=De+provincie+Li mburg+als+lerende+organisatie (accessed on 22 July 2019).

131. Reed, M.S.; Evely, A.C.; Cundill, G.; Fazey, I.; Glass, J.; Laing, A.; Newig, J.; Parrish, B.; Prell, C.; Raymond, C.; et al. What is social learning? Ecol. Soc. 2010, 15, 10. [CrossRef]

132. Kenter, J.O.; Reed, M.S.; Fazey, I. The Deliberative Value Formation model. Ecosyst. Serv. 2016, $21,194-207$. [CrossRef]

133. Sinek, S. Start with Why. How Great Leaders Inspire Everyone to Take Action; Penguin Group: New York, NY, USA, 2009; p. 245. Available online: https://books.google.nl/books?hl=nl\&lr=\&id=iyw6ul1x_n8C\&oi=fnd $\& p g=$ PR9\&dq=what + how + why+sinek\&ots=UMF5jYxx00\&sig=v1_f5cEslpr8cebrIDgjHvW1-cQ\#v=one page\&q=what/how/why/sinek\&f=false (accessed on 30 August 2019).

134. Wierdsma, A.; Swieringa, J. Lerend organiseren. Als meer van hetzelfde niet helpt. In Lerend Organiseren, 4th ed.; Noordhoff: Groningen/Utrecht, The Netherlands, 2017; p. 24, (out of 206); Available online: https://www.managementboek.nl/code/inkijkexemplaar/9789001876951/lerend-organiseren-en-ver anderen-andre-wierdsma.pdf (accessed on 25 August 2019).

135. Argyris, C. A Life Full of Learning. Organ. Stud. 2003, 24, 1178-1192. [CrossRef]

136. Mommaas, H.; Latour, B.; Scruton, R.; Schmid, W.; Mol, A.; Schouten, M.; Dammers, E.; Slob, M.; Muilwijk, H. Nature in Modern Society Now and in the Future; PBL: Den Haag, The Netherlands, 2017; p. 120. Available online: http://themasites.pbl.nl/natureoutlook/2016/ (accessed on 25 July 2018).

137. Berkes, F.; Colding, J.; Folke, C. Navigating Social-Ecological Systems. Building Resilience for Complexity and Change; Cambridge University Press: Cambridge, UK, 2003; p. 393.

138. Fischer, J.; Gardner, T.A.; Bennett, E.M.; Balvanera, P.; Biggs, R.; Carpenter, S.; Daw, T.; Folke, C.; Hill, R.; Hughes, T.P.; et al. Advancing sustainability through mainstreaming a social-ecological systems perspective. Curr. Opin. Environ. Sustain. 2015, 14, 144-149. [CrossRef]

139. Vader, J.; Roza, P.; Selnes, T.; Gaaff, A. Natuurcompensatie over de grens. In Een Analyse van natuurcompensatie in Het Buitenland; LEI: Den Haag, The Netherlands, 2007; p. 105. Available online: http://www.lei.dlo.nl/pub licaties/PDF/2007/6_xxx/6_07_15.pdf (accessed on 6 September 2019).

140. Van Damme, A. Habitat Banking. De Compensatie van Schade aan Natuurgebieden. Ph.D. Thesis, Ghent University, Gent, Belgium, 2012; p. 107. Available online: https://ib.ugent.be/fulltxt/RUG01/001/892/0 31/RUG01-001892031_2012_0001_AC.pdf (accessed on 21 July 2019).

141. GLOBIO. Modelling Human Impacts on Biodiversity. Available online: https://www.globio.info/what-is-gl obio/how-it-works/impact-on-biodiversity (accessed on 2 September 2019).

142. Bal, D.; Bal, D.; Beije, H.; Felllinger, M.; Haveman, R.; Van Opstal, A.; Van Zadelhoff, F. Handboek Natuurdoeltypen, 2nd ed.; Ministerie van Landbouw, Natuurbeheer en Visserij: Wageningen, The Netherlands, 2001; p. 832.

143. Janssen, J.; Schaminée, J. Europese Natuur in Nederland. Habitattypen; KNNV: Utrecht, The Netherlands, 2003; p. 120.

144. Schaminée, J.; Stortelder, A.; Westhoff, V. De vegetatie van Nederland. Deel 1. Inleiding tot de Plantensociologie: Grondslagen, Methoden en Toepassingen; Opulus Press: Uppsala, Sweden; Leiden, The Netherlands, 1995; p. 296.

145. Schaminée, J.; Weeda, E.; Westhoff, V. De Vegetatie van Nederland. Deel 2. Wateren, Moerassen en Natte Heiden; Opulus Press: Uppsala, Sweden; Leiden, The Netherlands, 1995; p. 360.

146. Schaminée, J.; Stortelder, A.; Weeda, E. De Vegetatie van Nederland. Deel 3. Plantengemeenschappen van Graslanden, Zomen en Droge Heiden; Opulus Press: Uppsala, Sweden; Leiden, The Netherlands, 1996; p. 356.

147. Schaminée, J.; Weeda, E.; Westhoff, V. De Vegetatie van Nederland. Deel 4. Plantengemeenschappen van de Kust en van Binnenlandse Pioniermilieus; Opulus Press: Uppsala, Sweden; Leiden, The Netherlands, 1998; p. 346.

148. Stortelder, A.; Schaminée, J.; Hommel, P. De Vegetatie van Nederland. Deel 5. Plantengemeenschappen van Ruigten, Struwelen en Bossen; Opulus Press: Uppsala, Sweden; Leiden, The Netherlands, 1999; p. 376.

149. Schaminée, J.; Haveman, R.; Hommel, P.; Janssen, J.; De Ronde, I.; Schipper, P.; Weeda, E.; Van Dort, K.; Bal, D. Revisie Vegetatie van Nederland; Uitgeverij Westerlaan-Publisher: Lichtenvoorde, The Netherlands, 2017; p. 232.

150. Nature and Landscape Index. Available online: https://www.bij12.nl/onderwerpen/natuur-en-landschap/ind ex-natuur-en-landschap/de-index-natuur-en-landschap/ (accessed on 15 March 2019). 
151. National Database Flora and Fauna. Available online: https://www.ndff.nl (accessed on 15 March 2019).

152. De Landelijke Vegetatie Databank. Available online: http://www.synbiosys.alterra.nl/natura2000/googlema pslvd.aspx (accessed on 15 March 2019).

153. Schaminée, J.; Janssen, J.; Haveman, R.; Hennekens, S.; Heuvelink, G.; Huiskes, H.; Weeda, E. Schatten voor de Natuur. Achtergronden, Inventaris en Toepassingen van de Landelijke Vegetatie Databank; Alterra: Wageningen, The Netherlands, 2006; p. 112.

154. Escobar, A. Whose Knowledge, Whose nature? Biodiversity, Conservation, and the Political Ecology of Social Movements. J. Political Ecol. 1998, 5, 53-82. [CrossRef]

155. Small, N.; Munday, M.; Durance, I. The challenge of valuing ecosystem services that have no material benefits. Glob. Environ. Chang. 2017, 44, 57-67. [CrossRef]

156. Sierdsema, H.; Hallmann, C.; Van Kleunen, A. Technische Documentatie "Kansenkaarten"; SOVON Vogelonderzoek Nederland: Nijmegen, The Netherlands, 2013; p. 71. Available online: https://www.ndff.nl /wp-content/uploads/2016/06/technische-documentatie-kansenkaarten.pdf (accessed on 5 September 2019).

157. Hotspot Monitor. Available online: https://www.rug.nl/about-us/news-and-events/video/archive/unifocus/d e-hotspotmonitor; https://www.rug.nl/society-business/centre-for-information-technology/research/services/ gis/portfolio/projecten/the-hotspotmonitor; http://www.hotspotmonitor.nl/hotspotsite/?page=4 (accessed on 2 September 2019).

158. Atlas Natural Capital. Available online: https://www.atlasnatuurlijkkapitaal.nl (accessed on 2 September 2019).

159. Atlas for Municipalities. Available online: https://www.atlasvoorgemeenten.nl (accessed on 2 September 2019).

160. EU Emissions Trading System (EU ETS). Available online: https://ec.europa.eu/clima/policies/ets_en (accessed on 9 February 2020).

161. Needham, K.; De Vries, F.P.; Armsworth, P.R.; Hanley, N. Designing markets for biodiversity offsets: Lessons from tradable pollution permits. J. Appl. Ecol. 2019, 56, 1429-1435. [CrossRef]

162. Commissie voor de Milieueffectrapportage. Available online: https://www.commissiemer.nl (accessed on 21 December 2019).

163. Nationaal Groenfonds. Available online: https://www.nationaalgroenfonds.nl (accessed on 21 December 2019).

164. METTA Standaard. Available online: https://metta-standaard.org/en/top-2/home-en/ (accessed on 24 August 2019).

165. Face the Future. Available online: https://facethefuture.com. (accessed on 24 August 2019).

166. Rijksdienst voor Ondernemend Nederland. Available online: https://www.rvo.nl (accessed on 24 August 2019).

167. Bos- en Natuur Compensatie. Available online: http://www.bosennatuurcompensatie.nl (accessed on 24 August 2019).

168. Funtowicz, S.O.; Ravetz, J.R. The worth of a songbird: Ecological economics as a post-normal science. Ecol. Econ. 1994, 10, 197-207. [CrossRef]

169. Buijs, A.; Mattijssen, T.; Arts, B. "The man, the administration and the counter-discourse": An analysis of the sudden turn in Dutch nature conservation policy. Land Use Policy 2014, 38, 676-684. [CrossRef]

170. Klain, S.C.; Olmsted, P.; Chan, K.M.; Satterfield, T. Relational values resonate broadly and differently than intrinsic or instrumental values, or the New Ecological Paradigm. PLoS ONE 2017, 12, 1-13. [CrossRef]

171. Batavia, C.; Nelson, M.P. For goodness sake! What is intrinsic value and why should we care? Biol. Conserv. 2017, 209, 366-376. [CrossRef]

172. Justus, J.; Colyvan, M.; Regan, H.; Maguire, L. Buying into conservation: Intrinsic versus instrumental value. Trends Ecol. Evol. 2009, 24, 187-191. [CrossRef]

173. Van den Born, R.J. Thinking Nature. Everyday Philosophy of Nature in The Netherlands. Ph.D. Thesis, Radboud University, Nijmegen, The Netherlands, 4 July 2007; p. 184.

174. Vucetich, J.A.; Bruskotter, J.T.; Nelson, M.P. Evaluating whether nature's intrinsic value is an axiom of or anathema to conservation. Conserv. Biol. 2015, 29, 321-332. [CrossRef]

175. Dearing, J.A.; Wang, R.; Zhang, K.; Dyke, J.G.; Haberl, H.; Hossain, M.S.; Langdon, P.G.; Lenton, T.M.; Raworth, K.; Brown, S.; et al. Safe and just operating spaces for regional social-ecological systems. Glob. Environ. Chang. 2014, 28, 227-238. [CrossRef] 
176. Hossain, M.S.; Dearing, J.A.; Eigenbrod, F.; Johnson, F.A. Operationalizing safe operating space for regional social-ecological systems. Sci. Total Environ. 2017, 584, 673-682. [CrossRef]

177. NDFF Kansenkaart. Available online: https://www.bij12.nl/onderwerpen/natuur-en-landschap/productenca talogus/portals/nationale-databank-flora-en-fauna-ndff/ndff-kansenkaart/ (accessed on 24 December 2019).

178. Overzicht Kansenkaarten. Available online: https://www.ndff.nl/overdendff/toepassingen/kansenkaarten/o verzicht-kansenkaarten/ (accessed on 24 August 2019).

179. Floron. Available online: https://www.floron.nl/onderzoek/verspreidingsonderzoek (accessed on 24 August 2019).

180. Hennekens, S.; Smits, N.; Schaminée, J. SynBioSys Nederland versie 2; Alterra: Wageningen, The Netherlands, 2010.

181. SynBioSys, N.L. Syntaxonomisch Biologisch KennisSysteem. Available online: https://www.synbiosys.alterr a.nl/synbiosysnl/ (accessed on 6 January 2020).

(C) 2020 by the authors. Licensee MDPI, Basel, Switzerland. This article is an open access article distributed under the terms and conditions of the Creative Commons Attribution (CC BY) license (http://creativecommons.org/licenses/by/4.0/). 